\title{
Transnational History and the History of a Nation: The Case of Estonia
}

\author{
Karsten Brüggemann \\ Tallinn University, School of Humanities, Centre of History, \\ Archaeology and Art History, Uus-Sadama 5, IOI2o Tallinn, \\ karsten.bruggemann@tlu.ee
}

\begin{abstract}
This article introduces the special issue of Acta Historica Tallinnensia on the potential and challenges of the 'transnational turn' for writing Estonian history. It outlines the general ideas behind the concept of transnational history, the historiographical debates surrounding it, and the place of Eastern Europe (in particular Estonia) within the field. Moreover, it introduces the contributions of this issue and discusses questions for further research.
\end{abstract}

Keywords: transnational history; global history; national history; history writing; imagined noncommunities; Eastern Europe; Russia; Soviet Union; Estonia

\section{INTRODUCTION}

"In some ways", the Irish historian Niall Whelehan wrote, "talking about transnational Irish history is stating the obvious." ${ }^{1}$ In a similar vein, this is also true of Estonia. Writing Estonian history exemplifies how contexts that go "beyond the nation" have always been vital to understanding the country's past. From the age of Christianisation and colonisation of the

I Whelehan, N. Playing with Scales: Transnational History and Modern Ireland. Transnational Perspectives on Modern Irish History. Ed. by N. Whelehan. Routledge, New York and London, 20I5, 7-29, quotation: 7. On transnational Irish history, see Delaney, E. Our Island Story? Towards a Transnational History of late Modern Ireland. Irish Historical Studies, 20II, 37 (I48), 599-62I. 
early thirteen th century, to the impact Sovietisation had on the country in the mid-twentieth century, Estonia - in contrast to Ireland - was never an island. The region was geographically open to various kinds of political, social, cultural, demographic and other forms of influence. The processes of globalisation, which started to connect the world from the nineteenth century, ${ }^{2}$ did not stop at the frontiers of the Russian Empire, nor at the borders of the Soviet bloc, and pushed post-Soviet Estonia into the global arena after 1991. Today, the huge impact of Estonia's national marketing strategy as a digital wunderkind and the innovative concept of e-residency proves that even a tiny country on the eastern shore of the Baltic Sea can go global. In a similar vein, migration, inward and outward, has shaped the demographics of the country since the aforementioned period of colonisation, even if local Estonians migrated in large numbers only from the nineteenth century onwards, either to the growing cities of the Baltic provinces or to other regions of the vast Russian Empire. If "foreign rule" was the continuous experience of Estonian lands and peoples from the Catholic conquest, then it goes without saying that this local historical condition generated a constant influx of practices, ideas, beliefs, habits, etc., the transfer of which lays at the bottom of what we understand as transnational history.

As archaeology has shown, due to its geographical location the exchange of goods via the territory of today's Estonia and the Baltic Sea dates back even further than early thirteenth century. ${ }^{3}$ The image of a small country connected to the wider world via trade has been popularised, among others, by Lennart Meri (1929-2006), Estonia’s first

2 For fascinating syntheses, see Bayly, C. A. The Birth of the Modern World I780-I9I4. Blackwell, Oxford, 2004; Bayly, C. A. Remaking the Modern World 1900-20I5: Global Connections and Comparisons. Wiley Blackwell, Hoboken, 20I8; Pomeranz, K., Topik, S. The World that Trade Created: Society, Culture, and the World Economy, I40o - the Present. Sharpe, Armonk, 1999; Pomeranz, K. The Great Divergence: China, Europe, and the Making of the Modern World Economy. Princeton University Press, Princeton, 20oo; Armitage, D. The Declaration of Independence: A Global History. Harvard University Press, Cambridge, MA, 2008; and, Osterhammel, J. Die Verwandlung der Welt. Eine Geschichte des 19. Jahrhunderts. Beck, München, 2009 (trans. as The Transformation of the World: A Global History of the Nineteenth Century. Princeton University Press, Princeton, 20I4). See the book series: Empires and Encounters, I350-I750 (A History of the Modern World, 3.) Ed. by W. Reinhard. The Belknap Press of Harvard University Press, Cambridge, MA, 20I5; An Emerging Modern World, I750-1870 (A History of the Modern World, 4.) Ed. by S. Conrad, J. Osterhammel. The Belknap Press of Harvard University Press, Cambridge, MA, 2018; A World Connecting, 1870-1945 (A History of the Modern World, 5.) Ed. by E. S. Rosenberg. The Belknap Press of Harvard University Press, Cambridge, MA, 2012; Global Interdependence. The World after 1945 (A History of the Modern World, 6.) Ed. by A. Iriye. The Belknap Press of Harvard University Press, Cambridge, 20I4; and, The Cambridge World History. Ed. by M. E. Wiesner-Hanks. Vols. I-7, 2. Cambridge University Press, Cambridge, 2015.

3 Valk, H., Šnē, A. Vor- und Frühgeschichte. - Das Baltikum. Geschichte einer europäischen Region. Bd. I: Von der Vor- und Frühgeschichte bis zum Ende des Mittelalters. Hrsg. von K. Brüggemann, D. Henning, K. Maier, R. Tuchtenhagen. Stuttgart 2018, 77-I43. 
president after the country re-gained its independence. Meri repeatedly stressed the historically grown trade network of Estonia's capital in his speeches. In Kraków in November 1998 he pointed out that Tallinn's

historical Marketplace is a small square at the crossing of three streets. [...] [T] he shortest street would take you to the port and along the Baltic Sea and on to France. The second street beginning from the marketplace takes you across the continent to Vienna, in other words to Rome, and the third to the East, to the springs of large rivers and further on along the Volga River and the Caspian Sea to Baghdad. ${ }^{4}$

Thus, in terms of shaping Estonia's image as a post-Soviet state, the Estonia's transnational past gained some importance and visibility during the ig9os.

If, thus, the country's geographic location at the crossroads of ancient and contemporary trade routes makes Estonia a fine example for studying interconnectedness and transcultural influences, the charms of the transnational approach have not yet received the attention they deserve among Estonian historians, something that makes the country similar to Ireland. ${ }^{5}$ The resilience of the nation-state framework for writing Estonian history is remarkable - and at the same time easily explainable. History writing today is still pretty much operating within the frame of the nation state globally. Moreover, in Eastern Europe, and Estonia in particular, the re-gaining of independence after the collapse of the Soviet Union shifted the attention of historians to topics that reaffirmed national identification. Among them were, most prominently, the period of independence between the World Wars (including the War of Independence 1918-1920) and the politically relevant issue of Sovietisation (including Soviet terror during Stalinism). The last period of "foreign rule" during the second half of the twentieth century is usually conceptualised as a phenomenon that threatened the existence of the nation, at least in the long run. Apart from this politically motivated conjuncture in focusing on the particular experience of national victimhood, other reasons also appear. Among the older generation of

4 Meri, L. Remarks of the President of the Republic at the Jagellonia University of Krakow, 30 April I998. URL: https://vpI992-20oI.president.ee/eng/k6ned/K6ne.asp?ID=435I (last accessed 6 October 2020).

5 Whelehan, N. Playing with Scales. For transnational history in states with culturally divided populations, Canada and Belgium, and the domination of national history writing there, see Dubinsky, K., Perry, A., Yu, H.: Introduction: Canadian History, Transnational History. - Within and Without the Nation. Canadian History as Transnational History. Ed. by K. Dubinsky, A. Perry, H. Yu. University of Toronto Press, Toronto, 20I5, 3-23; and, Van Ginderachter, M., Warland G. How Regional, National and Transnational History Has (Not) Been Written in Belgium: Reflections within a European Perspective. - Transnational Challenges to National History Writing. Ed. by M. Middell, L. Roura.

Palgrave Macmillan, Basingstoke, 2013, 404-422. 
historians there is a certain reluctance to use theoretical schemes that is caused in no small measure by the methodological dictate of historical materialism during the Soviet period. Yet there is also the well-founded belief that if nobody else is dealing with "our" history, even if it might feel awkwardly "local" from the outside, "we" need to focus on it ourselves. ${ }^{6}$

This might be a question of labelling. After all, why do Estonian historians need to follow explicitly every turn in global historiography if they deal with corresponding issues anyway, only without using trendy terms? The further you go back into the Estonian past, the more you have to deal with "foreign" networks, practices and traditions, not least because of the scarcity of documentation originating from the native inhabitants. Thus, apart from archaeological artefacts, there are mainly texts filtered through the colonisers' eyes telling us about the country prior to the modern period. Written sources therefore are generally examples of intercultural perception that in their essence mirror transcultural processes. It is, so to say, a transnational virtue in itself that recent Estonian historiography in general tends to view, for example the Teutonic Order and Catholic Church hierarchs as particular representations of the "local" resp. the "European" in history and not as "foreign intruders" as a nationalistic approach would have dictated.

Yet it seems to be precisely this kind of affirmative mainstream approach to the un-Estonian aspects of the local past that provoked interventions of the kind of Enn Tarvel's A Story of the Estonian People (2018). ${ }^{7}$ An achievement in itself, because it is a rare pleasure to read a history of the nation written by a single author of Estonian origin, this book sparked controversy first and foremost among Tarvel's colleagues, with whom he polemicises on the pages of his book, sometimes even without mentioning their names. In focusing on exactly those periods when the Estonian people gained or lost their "independence", Tarvel's

6 Kivimäe, J. Re-writing Estonian History? - National History and Identity: Approaches to the Writing of National History in the North-East Baltic Region, Nineteenth and Twentieth Centuries. Ed. by M. Branch. (Studia Fennica, 6.) Finnish Literary Society, Helsinki, 1999, 205-212; Kivimäe, J., Kivimäe, S. Geschichtsschreibung und Geschichtsforschung in Estland 1988-200I. - Osterreichische Osthefte, 2002, 44, I/2, I59-I70; and, Brüggemann, K. "Wir brauchen viele Geschichten". Estland und seine Geschichte auf dem Weg nach Europa? - GegenErinnerung. Geschichte als politisches Argument im Transformationsprozeß Ost-, Ostmittel- und Südosteuropas. (Schriften des Historischen Kollegs, 6I.) Hrsg. von H. Altrichter. Oldenbourg, München, 2006, 27-50.

7 Tarvel, E. Eesti rahva lugu. Varrak, Tallinn, 2018. The sharp public debate provoked in 2012 when a group of mainly young historians published the second volume of a "History of Estonia" in the Middle Ages may be a case in point here. For relevant literature, see Brüggemann, K. Five Letters on the Roof: National Narratives and the Soviet Past in Estonia. - The New Heroes - The Old Victims. Politics of Memory in Russia and the Baltics. Ed. by I. Gubenko, D. Hanovs, V. Mlahovskis. Zinatne, Riga, 2016, 50-59. 
"story" fits perfectly into the traditional grand narrative of Estonian history that Marek Tamm has aptly named "The Great Battle for Freedom".

In Tarvel's reading, the centuries of foreign rule are of interest only insofar as the plight of the Estonian peasants progressively worsened under various forms of slavery. The fact that even the idea of nations and national independence is of foreign origin does not play a role in his narrative, which, according to the author, reflects the expectations of an audience who is not interested in a variety of different interpretations of history. For him, there are "crystallised understandings, generally taken as natural and trustworthy" which deserve to be presented to a non-academic reader. ${ }^{9}$ If modern and diverse approaches to the past, even a multitude of different histories, are "acceptable on the international scholarly landscape", where Estonian historians naturally strive to stand, the ordinary local reader, according to Tarvel, needs a "self-centred approach to history". ${ }^{10}$

Obviously, even if experts may correctly remark that the concept of "ethnicity", as such, did not play much of a role prior to the nineteenth century, ${ }^{11}$ there is a societal need and an audience for such decidedly national approaches to the past. As has been noted by Bernhard Struck, Kate Ferris, and Jacques Revel, it is much more difficult to define an audience for transnational histories than for national ${ }^{12}$ - or, for that matter, global - histories. ${ }^{13}$ This chapter nevertheless explores what transnational perspectives have to offer the history of Estonia and why

8 Tamm, M. History as Cultural Memory: Mnemohistory and the Construction of the Estonian Nation. - Journal of Baltic Studies, 2008, 39, 4, 499-516.

9 Tarvel, E. Eesti rahva lugu, 9.

Io Tarvel, E. Eesti rahva lugu, 32. For a general critique, see Kaljundi, L. Ajaloovaidlustest, tóest ja dialoogist. - Sirp, 20 April 20I8. Concerning the case of the historiography of Ukraine, it has been stated that the "problem is not so much nationalized history itself, with its rather archaic cognitive and classifying apparatus, its orientation on satisfying ideological demand, and its intellectual hermeticism (for it is entirely self-sufficient). The problem lies, rather, in its extensive mass self-replication, which creates conditions uncongenial to the diversification of intellectual space and to the establishment and existence of other versions of both nationalized history and national histories in the framework of Ukrainian history, to say nothing of the possibility of creating transnational histories of Ukraine." Kasianov, G. "Nationalized" History: Past Continuous, Present Perfect, Future... - A Laboratory of Transnational History. Ukraine and Ukrainian Historiography since 1991. Ed. by G. Kasianov, P. Ther. Central European University Press, Budapest, 2009, 7-23, quotation: 22. It seems that in Estonia the situation is much more favourable to the transnational approach.

II Selart, A. Eestlaste oma ajalooteadus. - Keel ja Kirjandus, 20I8, I-2, 4I-49.

I2 Struck, B., Ferris, K., Revel, J. Introduction: Space and Scale in Transnational History. International History Review, 20II, 33, 4, 573-584, quotation: 577.

I3 Osterhammel, J. Global History (with a comment by P.-Y. Saunier and a response by Osterhammel). - Debating New Approaches to History. Ed. by M. Tamm, P. Burke. Bloomsbury, London, 20I9, 2I-47, quotation: 22 . For the popularity of global history see the series of small books on the global history of various foodstuff and drinks such as rum, gin, tea, as well as pizza, hot dogs and curry, published by Reaktion Books. See, for example, Weiss, L. Ice Cream: A Global History. Reaktion Books, London, $201 I$. 
this might be attractive to a larger audience not only internationally, but also nationally. Therefore, this introduction to this special issue of Acta Historica Tallinnensia sets out the main concepts and definitions of transnational history, assesses the major challenges and scrutinises the intimate relationship between the transnational and the national. It will address the question of why transnational history has become quite popular just now and only in certain historiographies, especially in some regions of Europe and in the USA. A further section will then outline general lines for a transnational framework, focussing primarily on modern Estonian history where, in contrast to the earlier period, transnational directions are much less present in scholarship. Finally, this chapter introduces the contributions to this special issue, which is the product of a project supported by the Estonian Research Council running from 2015 to $2020 .^{14}$

\section{VIRTUES AND CHALLENGES OF TRANSNATIONAL HISTORY}

A transnational frame for writing Estonian history offers an alternative to the historiographical tradition based on the concept of Kulturnation, which is so typical of Eastern European historical thought since 199I, ${ }^{15}$ and to the narrative template of the Great Battle for Freedom. Transnational history focuses, among others, on parallel realities that accompanied the nation-building process. As a perspective on the past it has, pretty much like the concept of nation itself, a prehistory avant la lettre that dates back to pre-modern and pre-national times as universal history. Today, transnational history serves as an umbrella perspective pushed by the growing interest of scholars in processes that went across state borders - transfers, connections, circulations, etc. Seen as a pragmatic approach, a way of viewing, not backed by any kind of elaborated theory or particular method of research, there is a broad consensus that methodological openness is a virtue of transnational history. ${ }^{16}$

I4 A Transnational Setting for Estonian History: Transcultural Entanglements, International Organisations and Transborder Migrations (I6th-2Ist Centuries) (IUT3I-6).

I5 See the essays in GegenErinnerung.

I6 "Fortunately, there are many different ways of doing transnational history." Osterhammel, J. A 'Transnational' History of Society. Continuity of New Departure? - Comparative and Transnational History. Central European Approaches and New Perspectives. Ed. by H.-G. Haupt, J. Kocka. Berghahn, New York, 2009, 39-51, quotation: 49. Osterhammel's recent remark that the threshold of acceptance in the case of Global History would have been much higher if "all global history nailed orthodox postcolonialism to its mast" is, of course, true also for Transnational History. Osterhammel, J. Global History, 4I; 
A transnational setting for the history of a nation can deal with all sorts of transfers and cross-cultural contacts, networks, etc. In the Palgrave Dictionary of Transnational History, Akira Iriye and Pierre-Yves Saunier describe transnational history as a set of "links and flows", as "people, ideas, products, processes and patterns that operate over, across, through, beyond, above, under, or in-between politics and societies" ${ }^{17} \mathrm{It}$ can focus on "flows and streams", the "movements of goods, technology and people", and on "exchange of culture and ideas", "models, practices, and images" ${ }^{18}$ A transnational frame concentrates on cross-cultural entanglements, "whether through individuals, non-national identities, and non-state actors", ${ }^{19}$ and is in general more sensitive to aspects such as the permeability of borders and boundaries, or territoriality and the ordering of space, than traditional international history or Gesellschaftsgeschichte. ${ }^{20}$

This relatively recent approach already has its own history (and its own Palgrave Dictionary) ${ }^{21}$ and thus has been around long enough to survive accusations of being just a fashionable "new hot thing". ${ }^{22}$ Even more so, it appears that the transnational is deeply rooted in the past of history writing. ${ }^{23}$ This fact has been turned into an argument against this perspective by some critics who rightly pointed out that transnational history is not entirely new. In the words of the doyen of German historical social research, Hans-Ulrich Wehler (193I-20I4),

Bayly, C., Beckert, S., Connelly, M., Hofmeyr, I., Kozol, W., Seed, P. AHR Conversation: On Transnational History. - American Historical Review, 2006, III, 5, I440-I465, here I454; and, Conrad, S., Osterhammel, J. Einleitung. - Das Kaiserreich transnational. Deutschland in der Welt 187I-1914. Hrsg. von S. Conrad, J. Osterhammel. Vandenhoeck \& Ruprecht, Göttingen, 2004, 7-27, quotation: I4-I5.

I7 Iriye, A., Saunier, P.-Y. The Professor and the Madman. - The Palgrave Dictionary of Transnational History. Ed. by A. Iriye, P.-Y. Saunier. Palgrave Macmillan, Basingstoke, 2009, XVII-XX, quotation: XVIII. On the question how the Japanese born Iriye (b. 1934) who as a classical diplomatic historian for decades teaches in the USA and Japan, and the French born Saunier (b. 1963) who as an expert on French urban history works in Canada can stand for inter-generational, inter-continental and inter-topical cooperation epitomising the rise of transnational history, see Patel, K. K. An Emperor without Clothes? The Debate about Transnational History Twenty-Five Years on. - histoire@politique, 20I5, 26. URL: http://www.histoire-politique.fr/index.php? numero $=26 \& \mathrm{rub}=$ pistes\&item $=32$ (last accessed 7 December 2020).

I8 Bayly, C. et al., On Transnational History, I440; David-Fox, M. The Implications of Transnationalism. - Kritika: Explorations in Russian and Eurasian History, 20II, I2, 4, 885-904, quotation: $885-886$.

I9 Iriye, A. Global and Transnational History: The Past, Present, and Future. Palgrave Macmillan, Basingstoke, 2013, I5.

20 Osterhammel, J. A 'Transnational' History of Society, 47.

2I The Palgrave Dictionary of Transnational History. See also The Routledge Handbook of Transregional Studies. Ed. by M. Middell. Routledge, London, 2018.

22 Whelehan, N. Playing with Scales, 8.

23 Patel, K. K. An Emperor without Clothes?; and, Stelzel, P. Transnationalism and the History of Historiography: A Transatlantic Perspective. - History Compass, 20I5, I3, 2, 78-87. On earlier non-academic uses of the term transnational, see Saunier, P.-Y. Transnational History. Palgrave Macmillan, Basingstoke, 2013, 13-32. 
one cannot speak of "a march into a Terra Incognita” because there are quite a number of well-established research areas in which transnational phenomena are traditionally in focus, such as empire studies, research on industrialisation and workers' history or the history of religions. ${ }^{24}$ Of course, in the case of workers' history, voluntary and forced migrations were influential factors of a transnational character, as were many strikes, forms of campaigning and the creation of international organisations. ${ }^{25}$ Indeed, historians have methodologically "crossed borders" since the nineteen th century in order to empirically study transnational phenomena, for example when they aimed to explain what is specific and what is general in their nation's history, which was (and is) possible to define only with the help of comparison with other countries. To understand, for example, the German Empire from a global, transnational point of view, was an innovative approach that has productively accompanied the "transnational turn" in German historiography since the beginning of the twenty-first century. ${ }^{26}$

Comparative history as a methodological toolkit established during the I970s is clearly one of the approaches transnational history can build upon in adding multiperspectivity as a heuristic principle in order to avoid distortions that could come from a nationally predetermined view. However, microhistory was also one of the ways historians tried to find an alternative to the dominant frames of national history during the final decades of the twentieth century. ${ }^{27}$ The subfield of

24 Wehler, H.-U. Transnationale Geschichte - der neue Königsweg historischer Forschung? - Transnationale Geschichte. Themen, Tendenzen und Theorien. Jürgen Kocka zum 65. Geburtstag. Hrsg. von G. Budde, S. Conrad, O. Janz. Vandenhoek \& Ruprecht, Göttingen, 2006, I6I-174, quotation: 163-167. Of course, other fields may come to mind as well, for example the history of ideas or business history. See the articles in the same volume Rothschild, E. Arcs of Ideas. International History and Intellectual History. Transnationale Geschichte, 217-226; and, Feldman, G. D. Business History, Comparative History, and Transnational History. - Transnationale Geschichte, 254-264.

25 Linden, M. v. d. Transnational Labour History: Explorations. Ashgate, Aldershot, 2003, 3. See Grenzüberschreitende Arbeitergeschichte: Konzepte und Erkundungen = Labour History Beyond Borders: Concepts and Explorations. Ed. by M. v. d. Linden, E. Himmelstoss. (ITH-Tagungsberichte, 44.) Akademische Verlagsanstalt, Leipzig, 2010. Interestingly enough, neo-Marxist political science expects "transnational solidarity emerging through processes of concrete class struggle" as global reactions of workers to neoliberal solutions. Bieler, A., Lindberg, I. Globalisation and the New Challenges for Transnational Solidarity: an Introduction. - Global Restructuring, Labour and the Challenges for Transnational Solidarity. Ed. by A. Bieler, I. Lindberg. (Rethinking Globalizations, 25.) Routledge, London, 20II, 3-I5, quotation: I4.

26 See, for example, Das Kaiserreich transnational. Deutschland in der Welt I87I-1914. Hrsg. von S. Conrad, J. Osterhammel. Vandenhoeck \& Ruprecht, Göttingen, 2006, and the recent analysis After the Imperialist Imagination: Two Decades of Research on Global Germany and Its Legacies. (Transnational Cultures, 3.) Ed. by D. Price, M. Krishnan, D. Pizzo, S. Pugach, A. Blackler, Peter Lang, Oxford, 2020.

27 See, for example, Levi, G. On Microhistory. - New Perspectives on Historical Writing. Ed. by P. Burke. Cambridge University Press, Cambridge, 1991, 93-II3; Warren Sabean, D. Reflections on Microhistory. - Transnationale Geschichte, 275-298; and, Ghobrial, J.-P. A. Introduction: Seeing the World like a Microhistorian. - Past \& Present, 2019, 242, Issue Supplement I4: Global History and Microhistory, I-22. 
border studies can be mentioned here as well, and studies investigating topics such as Europeanisation, Westernisation or Americanisation contributed to historians' growing understanding of the transfers and entanglements typical of historical processes that did not stop at the borders of nation-states. Evidently, at the same time, the environmental turn led to a new sensitivity to the role climatic changes have played in the past and stressed the need to go beyond national borders, which obviously play no role in processes that have a planetary impact, such as global warming. ${ }^{28}$ Recently, current "hot" cross-border topics such as terrorism, human rights, sport, tourism and the spread of disease and the consequences of disaster have gained attention from a transnational perspective..$^{29}$ During the last decade of the twentieth century, "entangled history" and "histoire croisée" became terms uttered in the same breath as transnational history. ${ }^{30}$ World history and/or global history became the object of a stimulating debate that aimed at a new understanding of universal history as something different than just a narrative form of adding or juxtaposing national histories. ${ }^{31}$ Despite the disputed

28 Quenet, G. Environmental History (with a comment by S. Sörlin and a response by G. Quenet). - Debating New Approaches to History, 75-Ioo.

29 Enders, W., Sandler, T., Gaibulloev, K. Domestic versus Transnational Terrorism: Data, Decomposition, and Dynamics. - Journal of Peace Research, 20II, 48, 3, 319-337; Entangled Protest: Transnational Approaches to the History of Dissent in Eastern Europa and the Soviet Union. (Einzelveröffentlichungen des Deutschen Historischen Instituts Warschau, 3I.) Ed. by R. Brier. Fibre, Osnabrück, 2013; Special Issue: Global and Transnational Sport: Ambiguous Borders, Connected Domains. Ed. by S. Naha. - Sport in Society, 2017, 20, IO; Tourism and Travel During the Cold War. Negotiating Tourist Experiences Across the Iron Curtain. Ed. by S. Bechmann Pedersen, C. Noack. Routledge, London, 2019; Chalk, P.: The Transnational Spread of Disease. - Chalk, P. Non-Military Security and Global Order. The Impact of Extremism, Violence, and Chaos on National and International Security. St. Martin's Press, New York, 2000, 95-II4; Spinney, L. Pale Rider. The Spanish Flu of I9I8 and how it Changed the World. Jonathan Cape, London, 2017. See transnational studies on the disaster in Chernobyl: Brown, K. Plutopia: Nuclear Families, Atomic Cities, and the Great Soviet and American Plutonium Disasters. Oxford University Press, Oxford, 20I3; Kalmbach, K. The Meanings of a Disaster: Chernobyl and Its Afterlives in Britain and France. Berghahn, New York, 202o; Arndt, M. Tschernobylkinder. Die transnationale Geschichte einer nuklearen Katastrophe. Vandenhoeck \& Ruprecht, Göttingen, 2020.

30 Osterhammel, J. Global History; Bayly, C. A. History and World History. - A Concise Companion to History. Ed. by U. Rublack. Oxford University Press, Oxford 20II, 3-26; Gallus, A., Schildt, A., Siegfried, D. Deutsche Zeitgeschichte - transnational. - Deutsche Zeitgeschichte - transnational. Hrsg. von A. Gallus, A. Schildt, D. Siegfried. Wallstein Verlag, Göttingen, 2015, II-23, quotation: I5-16; and, Werner, M., Zimmermann, B. Beyond Comparison: Histoire Croisée and the Challenge of Reflexivity. - History and Theory, 2006, 45, I, 30-50. See the articles in Comparative and Transnational History, and Hilton, M., Mitter, R. Introduction. - Past \& Present, 20I3, 218, Issue supplement 8: Transnationalism and Contemporary Global History, 7-28. With a focus on non-European aspects, see Pernau, M. Transnationale Geschichte. Vandenhoeck \& Ruprecht, Göttingen, 2011.

3I Geyer, M., Bright, C. World History in a Global Age. - American Historical Review, 1995, Ioo, 4, I034-IO60; Mazlish, B. Comparing Global History to World History. - The Journal of Interdisciplinary History, 1998, 28, 3, 385-395; The Global History Reader. Ed. by B. Mazlish. Routledge, New York, 20o5; Mazlish, B. The New Global History. Routledge, New York, 2006; Zenon Davis, N. What is Universal about History? - Transnationale Geschichte, 15-20; Conrad, S. What is Global History? Princeton University Press, Princeton, 2016; The Prospect of Global History. Ed. by J. Belich, J. Darwin, M. Frenz, C. Wickham. Oxford University Press, Oxford, 2016; Bayly, C. et al., On Transnational 
distinctions between these novel directions in history writing, they all belong to a family of relational approaches that challenge the nation as an analytical framework. ${ }^{32}$

Whereas the directions mentioned first in the preceding paragraph predate the current discourse of globalisation that was motivated not least by the end of the Cold War, the latter are accompanied the emergence of transnational history as a subfield in history from the r990s. Since then, scholars' sense of what might be a legitimate object of research has shifted. To most, it seems evident now that there is a history beyond national borders and that this history is more than inter-national, as Michael Geyer has asserted in a review of the volume that presented, among others, Wehler's critical essay. In contrast to Wehler, however, Geyer maintains that "entire new subjects, practices, and explanatory strategies have come about over the last few decades". ${ }^{33}$

Concerning recent developments in the field of history, however, it is important to remember how the discipline from the r980s onwards started to more systematically scrutinise its own nation-focused agenda and the processes that had made possible nation building, the spread of national identifications and the spirit(s) of nationalism. It was only then that the notion of nation became an object of research instead of serving as "a self-evident frame of reference", ${ }^{34}$ not least because of the seminal works by Benedict Anderson (1936-2015), Ernest Gellner (1925-1995), and Miroslav Hroch (b. 1932) on the "creation" or "invention" of modern

\footnotetext{
History; Osterhammel, J. Die Verwandlung; Ballantyne, T., Burton, A. Empires and the Reach of the Global. - A World Connecting, 85-43I; Global History, Globally. Research and Practice Around the World. Ed. by S. Beckert, D. Sachsenmaier. Bloomsbury, London, 20I8; and, The Practice of Global History: European Perspectives. Ed. by M. Middell. Bloomsbury, London 2019. Tracing the story of global history back into the era following the First World War, see Naumann, K. Laboratorien der Weltgeschichtsschreibung. Lehre und Forschung an den Universitäten Chicago, Columbia und Harvard I918 bis 1968. (Transnationale Geschichte 7.) Vandenhoeck \& Ruprecht, Göttingen, 2019. On Global Cultural History see the special edition ed. by Tamm, M. Global Cultural History. Cultural History, 2020, 9, 2, 135-264.

32 Werner, B., Zimmermann, B. Vergleich, Transfer, Verflechtung. Der Ansatz der Histoire croisée und die Herausforderung des Transnationalen. - Geschichte und Gesellschaft, 2002, 28, 4, 607-636; and, Ther, P., Comparisons, Cultural Transfers and the Study of Networks: Towards a Transnational History of Europe. - Comparative and Transnational History, 204-225.

33 Geyer, M. Transnational History - The New Consensus. Review on Transnationale Geschichte. Themen, Tendenzen und Theorien. Jürgen Kocka zum 65. Geburtstag. Hrsg. von G. Budde, S. Conrad, O. Janz. Vandenhoek \& Ruprecht, Göttingen, 2006. Forum: Reviewsymposium “Transnationale Geschichte,” H-Soz-u-Kult, II October 2006. URL: http://hsozkult.geschichte.hu-berlin.de/rezensionen/2006-4-032 (last accessed 23 October 2020).

34 This is rightly pointed out in Albert, M., Bluhm, G., Helmig, J., Leutzsch, A., Walter, J. Introduction: The Communicative Construction of Transnational Political Places. Transnational Political Spaces. Agents - Structures - Encounters. (History of Political Communication, I8.) Ed. by M. Albert, G. Bluhm, J. Helmig, A. Leutzsch, J. Walter. Campus, Frankfurt/New York, 2009, 7-3I, quotation: I5.
} 
nations in the late eighteenth and nineteenth century. ${ }^{35}$ This understanding of the culturally produced nature of nations was one of the essential factors that led scholars to the acknowledgment that writing the history of such nations is not necessarily the normal case in the history of historiography. ${ }^{36}$

Although the term transnational, as such, is much older, ${ }^{37}$ and came to be used in political science and sociology during the r970s and 198 os (and was already used by legal scholars in the I950s) ${ }^{38}$ the emergence of transnational history as a sub-field of historical science dates back to the early I990s. It was a (belated) reaction of (initially) US historians to global developments, which had taken place since the end of the Second World War and were difficult to comprehend solely in terms of the nation-state (decolonisation, economic globalisation, environmentalism, consumerism, etc.), or in the framework of the assumed exceptionalism prevailing in American history at that time. ${ }^{39}$ At the end of the decade, transnational history was also introduced in Germany by the editors of one of the major journals in the field, Geschichte und Gesellschaft, traditionally connected since its foundation in 1975 with the concept

35 Anderson, B. Imagined Communities. Reflections on the Origins and Spread of Nationalism. Verso, London, 1983; Gellner, E. Nations and Nationalism. Cornell University Press, Ithaca 1983; and, Hroch, M. Social Preconditions of National Revival in Europe. A Comparative Analysis of the Social Composition of Patriotic Groups among the Smaller European Nations. Cambridge University Press, Cambridge, 1985. Hroch's earlier German-language book on the same topic did not have the same impact, see Hroch, M. Die Vorkämpfer der nationalen Bewegung bei den kleinen Völkern Europas. Eine vergleichende Analyse zur gesellschaftlichen Schichtung der patriotischen Gruppen. Univ. Karlova, Praha, 1968). See also The Invention of Tradition. Ed. by E. Hobsbawm, T. Ranger. Cambridge University Press, Cambridge, 1983.

36 Osterhammel, J. Transnationale Gesellschaftsgeschichte, 474.

37 For a history of the term "transnational law", see Saunier, P.-Y. Transnational. - The Palgrave Dictionary of Transnational History, I047-IO55; and, Saunier, P.-Y. Learning by Doing: Notes about the Making of the Palgrave Dictionary of Transnational History. Journal for Modern European History, 2008, 6, 2, I59-180.

38 The term was used in political science in order to indicate usually neglected non-state actors and networks, such as business enterprises. See Nye, J. S., Keohane, R. O. Transnational Relations and World Politics: An Introduction. - International Organization, 1971, 25, 3 , 329-349; Kaiser, K. Transnational Politics: Toward a Theory of Multinational Politics. International Organization, 1971, 25, 3, 790-817; and, Mansbach, R. W., Ferguson, Y. H., Lampert, D. E. The Web of World Politics: Nonstate Actors in the Global System. PrenticeHall, Eaglewood Cliffs, 1976. For the notion of "transnational law", see Jessup, P. C. Transnational Law. Yale University Press, New Haven, 1956.

39 Iriye, A. The Internationalization of History. - American Historical Review, 1989, 94, I, I-IO; Tyrrell, I. American Exceptionalism in an Age of International History. - American Historical Review, I99I, 96, 4, I03I-IO55; McGerr, M. The Price of the 'New Transnational History'. - American Historical Review, 199I, 96, 4, I056-1067; Geyer, M., Bright, Ch. World History in a Global Age. - American Historical Review, I995, I00, 4, I034-IO60; Bayly, C. et al. On Transnational History; Tyrrell, I. Reflections on the Transnational Turn in United States History: Theory and Practice. - Journal of Global History, 2009, 4, 4, $453-474$. See also the introduction to a special issue Thelen, D. The Nation and Beyond: Transnational Perspectives on United States History. - Journal of American History, 1999, 86, 3, 965-975 (with sections on "Envisioning Transnational History," "Ways of Writing Transnational History" and "Transformation across Borders"). 
of Historische Sozialwissenschaft (history as a social science). ${ }^{40}$ This authoritative intervention to promote a transnational understanding of the history of society (Gesellschaftsgeschichte) served as a reply to the criticism that social history in Germany (and elsewhere) predominantly deals with society, politics, culture and economy in the framework of the nation-state. ${ }^{41}$ No doubt, the increasing interconnectedness especially in the (at least partially) supra-national framework of the European Union - and in the life experience of the scholars themselves - sharpened the eyes for the historical continuities of trans-border processes, primarily in former empires such as the United Kingdom, France ${ }^{42}$ and Germany. Iryie speaks even of a "transnational consciousness" promoted in particular by the European Union. ${ }^{43}$ This, however, leaves aside the fact that in many Eastern European post-socialist societies the transnational approach has not had a huge effect where socialist "internationalism" has been the octroyed norm for half a century (we will return to this question later in this chapter).

40 Raphael, L. Nationalzentrierte Sozialgeschichte in programmatischer Absicht. Die Zeitschrift "Geschichte und Gesellschaft. Zeitschrift für Historische Sozialwissenschaft" in den ersten 25 Jahren ihres Bestehens. - Geschichte und Gesellschaft, I999, 25, I, 5-37. On the debate, see Patel, K. K. "Transnations" among "Transnations"? The Debate on Transnational History in the United States and Germany. - American Studies, 2009, 54, 3, 45I-472.

4I In early 1999, the editors of "Geschichte und Gesellschaft" organised a colloquium that resulted in contributions to the debate published in 200I and 2002. See Osterhammel, J. Transnationale Gesellschaftsgeschichte: Erweiterung oder Alternative? - Geschichte und Gesellschaft, 20oI, 27, 3, 464-479; Spiliotis, S.-S. Das Konzept der Transterritorialität oder Wo findet Gesellschaft statt? - Geschichte und Gesellschaft, 200I, 27, 3, 48o-488; Wirz, A. Für eine transnationale Gesellschaftsgeschichte. - Geschichte und Gesellschaft, 20oI, 27, 3, 489-498; Conrad, S. Doppelte Marginalisierung. Plädoyer für eine transnationale Perspektive auf die deutsche Geschichte. - Geschichte und Gesellschaft, 2002, 28, I, I45169; Linden, M. v. d. Vorläufiges zur transkontinentalen Arbeitergeschichte. - Geschichte und Gesellschaft, 2002, 28, 2, 291-304; Werner, B., Zimmermann, B. Vergleich, Transfer, Verflechtung; Krieger, M. "Transnationalität” in vornationaler Zeit? Ein Plädoyer für eine erweiterte Gesellschaftsgeschichte der Frühen Neuzeit. - Geschichte und Gesellschaft, 2004, 30, I, I25-I36; zuvor bereits erschienen; and, Paulmann, J. Internationaler Vergleich und interkultureller Transfer. Zwei Forschungsansätze zur europäischen Geschichte des I8. bis 20. Jahrhunderts. - Historische Zeitschrift, 1998, 267, 3, 649-685. Some of these articles were published later in English in the collected volume Comparative and Transnational History.

42 Le travail et la nation. Histoire croisée de la France et de l'Allemagne. Ed. by B. Zimmermann, C. Didry, M. Wagner. Éd. de la Maison des Sciences de l'Homme, Paris, I999.

43 Iriye, A. Review: Transnational History. - Contemporary European History, 2004, I3, 2, 2II-222, quotation: 2II; and, Kasianov, G., Ther, P. Introduction. - A Laboratory of Transnational History: Ukraine and Ukrainian Historiography since 1991. Ed. by G. Kasianov, P. Ther. Central European University Press, Budapest, 2009, I-4, quotation: 3. Indeed, this term was used to describe a historical phenomenon - socialist reactions to fascism in the 1930 as early as 1996. Horn, G.-R. European Socialists Respond to Fascism: Ideology, Activism and Contingency in the 1930s. Oxford University Press, Oxford, 1996, II7-I36. See García, H. Transnational History: A New Paradigm for Anti-Fascist Studies? Contemporary European History, 2016, 25, 4, 563-572, here 564. On early impulses towards a comparative history of totalitarian movements, see Schönpflug, D. Histoires croisées: François Furet, Ernst Nolte and a Comparative History of Totalitarian Movements. European History Quarterly, 2007, 37, 2, 265-290. 
Yet the nation-state has served as key framework for historical analysis since the nineteenth century and, since then, historians have been at the forefront of the national project. Even if national histories were written earlier, it was the specific Romantic understanding of "nations" as collective bodies that made historians think about the unique character of any individual nation. Of course, colonialism and imperialism helped in spreading the ideas of European "scientific" history and European forms of modern nationalism globally, which in itself was a transnational process, although alternative approaches to the past continued to be influential around the globe, including Europe. ${ }^{44}$

Today, in a way that hardly anyone in the West expected after the end of the Cold War, the nation state is alive and remains to offer a convenient political solution for (post-national) societies despite (and even in) the supra-national frame of the European Union. No doubt, it is still a popular and possibly productive frame for historical research. Much like in the case of travel guides, history books continue to be produced about single states, at least for the wider public. Moreover, even histories of multinational empires, such as the Russian Empire, quite often focus on the dominant nation, in this case, the Russians. ${ }^{45}$ Certainly, we first need to acknowledge that Transnational History is no histoire totale trying to encompass virtually everything and, second, that not everything has a transnational dimension. Pierre-Yves Saunier has reminded us with a fitting allusion to J. R. R. Tolkien's The Lord of the Rings that the transnational perspective is not the one "ring to rule them all" ${ }^{46}$ It is rather a contemporary way of comprehending the past

44 Berger, S. Introduction: Towards a Global History of National Historiographies. - Writing the Nation: A Global Perspective. Ed. by S. Berger. Palgrave, London, 2007, I-29; Berger, S. The Power of National Pasts: Writing National History in Nineteenth- and TwentiethCentury Europe. - Writing the Nation, 30-62; Iggers, G. G., Wang, E., Mukherjee, S. A Global History of Modern Historiography. Pearson/Longman, Harlow, 2008; The Past as History: National Identity and Historical Consciousness in Modern Europe. Ed. by S. Berger, C. Conrad. Palgrave Macmillan, Basingstoke, 20I5; Tamm, M. Euroopa rahvuslik ajalookirjutus vôrdlevas vaatluses. - Tuna, 2017, 2, I28-138, and, Leerssen, J. Nation and Ethnicity. - The Contested Nation: Ethnicity, Class, Religion and Gender in National Histories. Ed. by S. Berger, C. Lorenz. Palgrave Macmillan, Basingstoke, 2008, 75-IO3. For the broader cultural context, see Encyclopedia of Romantic Nationalism in Europe. 2 vols. Ed. by J. Leerssen, A. H. v. Baal, J. Rock. Amsterdam University Press, Amsterdam, 2018.

45 By the way, this is true also in the case of non-dominant imperial nations such as the Ukrainians. See Kappeler, A. From an Ethnonational to a Multiethnic to a Transnational Ukrainian History. - A Laboratory of Transnational History, 51-80. In the case of the history of Russia, not even the authoritative Cambridge History of Russia (3 Vols. Cambridge University Press, Cambridge, 2006) leaves the traditional path of focussing on Russia and the Russians, although some chapters are included that cover the non-Russian territories of the empire. The field for research on the multinational character of the Empire was opened by Kappeler, A. Rußland als Vielvölkerreich. Entstehung, Geschichte, Zerfall. Beck, München, 1992 (trans. as The Russian Empire: A Multiethnic History. Longman, Harlow, 200I).

46 Saunier, P.-Y. Transnational History, I40-I4I. 
by adding new perspectives to former approaches in history writing, not denying them. Jan-Henrik Meyer explicitly warns that "methodological nationalism" should not be substituted with "methodological transnationalism" and, of course, there are vast domains of historical research that do not need a transnational view. ${ }^{47}$

Nevertheless, in the early twenty-first century, scholars registered an "excitement" about transnational history and the "worlds across borders" hitherto "absent from history" it endeavours to explore. ${ }^{48}$ In his ground-breaking The Birth of the Modern World $1780-1914$, Christopher Bayly (1945-2015) famously claimed that "all historians are world historians now, though many have not yet realized it" ${ }^{49}$ However, Bayly here does not so much embody this "excitement", but rather reflects the condition of history writing about (and in) a connected world. Historians cannot fully understand a place like Europe, or for that matter Estonia, without taking into account the larger (even global) contexts. Again, this is neither a new nor revolutionary insight and was elucidated by Frederick Jackson Turner (186I-I932) - who usually counts among the proponents of US exceptionalism - in the late nineteenth century, or by Marc Bloch (1886-1944) in the 1920s, to name but two. ${ }^{50}$ At the same time, as the late British expert on Southeast Asian history Bayly confirms himself, "evolutionary nationalist historicism" remains "the dominant form of historical understanding across much of the world" ${ }^{51}$ However, the environment of national history writing has changed considerably during recent decades. In this respect, the eminent historian of ideas David Armitage declares, not without a slightly provocative undertone, that "the hegemony of national historiography is over", and clams that if "you are not doing an explicitly transnational, international or global project, you now have to explain why you are not". ${ }^{52}$

47 Meyer, J.-H. Transnationale Geschichte. Eine Perspektive. - Historische Mitteilungen der Ranke-Gesellschaft 20I4, 26, I, 366-382. Similarly, on the limits of Global History, see Conrad, S. What is Global History?, I29-I32.

48 Geyer. M., Transnational History; Ransel, D. L. Reflections on Transnational and World History in the USA and Its Applications. - Historisk Tidskrift (S), 2007, I27, 4, 625-642; and, Jarausch, K. Reflections on Transnational History. - H-German, 20.I.2006. URL: https://lists.h-net.org/cgi-bin/logbrowse.pl?trx=vx\&list=h-german\&month=06or\&week= $c \& \mathrm{msg}=\mathrm{LPkNHirCmixgSZQKHOGRXQ \& user}=\& \mathrm{pw}=($ last accessed 23 October 2020 $)$

49 Bayly, C. A. The Birth of the Modern World, 469.

so Turner wrote, in I89I, "local history can only be understood in the light of the history of the world". Turner, F. J. The Significance of History. - Frontier and Section. Selected Essays of Frederick Jackson Turner. Ed. by R. A. Billington, Englewood Cliffs, 196I, II-28, quotation: 20-2I, quot. in Saunier, P.-Y. Transnational History, I. See also Bloch, M. Pour une histoire comparée des sociétés europeénnes. - Revue de synthèse historique, 1928, 46, I5-50.

5I Bayly, C. A. History and World History, I3; Middell, M., Roura, L. The Various Forms of Transcending the Horizon of National History Writing. - Transnational Challenges, I-35, quotation: Io.

52 Ittersum, M. v., Jacobs, J. Are We All Global Historians Now? An Interview with David Armitage. - Itinerario, 20I2, 3, 2, 7-28, quotation: 16; Ghobrial, J.-P. A. Introduction: Seeing the World like a Microhistorian, 3. 
As Iriye has maintained, transnational history does not deny the "intricate interrelationship between nations and transnational existence". ${ }^{53}$ No doubt, "nations and their subject(s) operate within the 'context' [...] of transnational movements, forces, and circuits", 54 which is, of course, true especially in the case of smaller nations like Estonia. A transnational frame thus is not meant to deconstruct (Estonian) nationalism as a driving force in history. It only questions the undisputed authority of the nation as an analytical framework. Recent scholarship has designed it "one of the central paradoxes" of transnational history that "transnational ties can dissolve some national barriers while simultaneously strengthening or creating others". ${ }^{55}$ If Rüger argues that the task for transnationally oriented historians is thus to show how the nation is "bound up with the global/transnational/cross-national past"s6 one might also add that the trans-boundary transnational is reciprocally shaped by the national - not the least because of the nations' power to regulate borders. ${ }^{57}$ Klaus Kiran Patel has rightly pointed out that borders are a prerequisite for studying the transnational because if they were completely porous and permeable, "transnational history would tend to lose its object of analysis" ${ }^{58}$ No doubt, nationalism is "of necessity transnationally constructed", which in turn means that the transnational and the national are not mutually exclusive, they are just two variations that focus on parallel though tightly connected developments in the past. ${ }^{59}$

This is proven especially by the promising field of biographical research into transnational actors, which has recently focussed on taking mobility, not nation, as the frame of research. Naturally, this approach is open for nationally indifferent "imagined noncommunities" (Tara Zahra) and individual experiences of those so far largely neglected actors who were not active as national entrepreneurs. ${ }^{60}$ Desley Deacon, Penny

53 Iriye, A. Global and Transnational History, I5. See also Tyrrell, I. Reflections on the Transnational Turn in United States History: Theory and Practice. - Journal of Global History, 2009, 4, 3, 453-474.

54 Geyer, M. Transnational History.

55 Clavin, P. Defining Transnationalism. - Contemporary European History, 2005, I4, 4, 42I-439, quotation: 43 I.

56 Rüger, J. OXO: Or, the Challenges of Transnational History. - European History Quarterly, 210, 40, 4, 656-668, quotation: 663 .

57 Middell, M., Naumann, K. Global History and the Spatial Turn. From the Impact of Area Studies to the Study of Critical Junctures of Globalization. - Journal of Global History, 2010, 5, I, I49-170, quotation: 159-160.

58 Patel, K. K. An Emperor without Clothes?

59 Verdery, K. Beyond the Nation in Eastern Europe. - Social Text, 1994, 38, I, I-19, here 5; Conrad, C. Vergleich und Transnationalität. - Oldenbourg Geschichte Lehrbuch. Neueste Zeit. Hrsg. von A. Wirsching, Oldenbourg Verlag, München, 2006, 317-332, quotation: 330; and, Albert, M., Bluhm, G., Helmig, J., Leutzsch, A., Walter, J. Introduction, I3. On Estonian nationalism, see Petersoo, P. Reconsidering Otherness: Constructing Estonian Identity. - Nations and Nationalism, 20IO, I3, I, II7-I33.

60 On the term, see Zahra, T. Imagined Noncommunities: National Indifference as a Category of Analysis. - Slavic Review, 20I0, 69, I, 93-II9. On the stimulating debate on the Germans 
Russel and Angela Woollacott have pointed out that mobility of individuals has been crucial to a modernising world, accelerated by new means of transport and communication and shaped by "structures of colonialism, slavery and indentured labour, globalizing economies, higher education, professional training, political upheaval, mixed marriages and cultural industries". ${ }^{61}$ The transnational lives of women in particular have become an object of research in order to contest the traditional understanding locating men in the "global" and females in the "local" arena and to make clear the potential of local empirical studies to challenge the big picture. ${ }^{62}$ At the same time, with a focus on continental Europe, (elite) mobility and autobiography in multinational empires such as Austria-Hungary, Turkey and Russia have become an object of research analysing how "imperial subjects" were the embodiment of empire and, at the same time, important agents of transfer between the various centres and peripheries of the empires in question. ${ }^{63}$

of the Baltic provinces of the Russian Empire and the Baltic states until World War II, see Baltic German Perceptions of Belonging in the Nineteenth and Twentieth Century (Special Issue). Ed. by K. Wezel, S. Donecker. - Journal of Baltic Studies, 20I7, 48, I, I-98; and, Brüggemann, K., Wezel, K. Nationally Indifferent or Ardent Nationalists? On the Options for Being German in Russia's Baltic Provinces, 1905-17. - Kritika: Explorations in Russian and Eurasian History, 2019, 20, I, 39-62.

6I Deacon, D., Russel, P., Woollacott, A. Introduction. - Transnational Lives. Biographies of Global Modernity, I70o - present. Ed. by D. Deacon, P. Russel, A. Woollacott. Palgrave Macmillan, Houndmills, 20IO, I-II, quotation: 2; Amelang, J. S. Transcultural Autobiography, or The Lives of Others. - Selbstzeugnis und Person. Transkulturelle Perspektiven. Ed. by C. Ulbrich, H. Medick, A. Schaser. (Selbstzeugnisse der Neuzeit, 20.) Böhlau, Cologne, 20I2, 77-85; and, Cott, N. F., Tuck, S., Allman, J., Pratt Guterl, M. AHR Forum: Transnational Lives in the Twentieth Century. - American Historical Review 20I3, II8, I, 45-I39. For a selection of intellectual biographies of Catholic Enlightenment figures in eighteenth-century Europe, see Enlightenment and Catholicism in Europe. A Transnational History. Ed. by J. D. Burson, U. L. Lehner. University of Notre Dame Press, Notre Dame, 20I4. From the perspective of social movements, see The Transnational Activist: Transformations and Comparisons from the Anglo-World since the Nineteenth Century. Ed. by S. Berger, S. Scalmer. Palgrave Macmillan, Cham, 2018. For a sociological perspective, see Davis, K. From Transnational Biographies to Transnational Cultural Spaces. - Handbuch Biographieforschung. Ed. by H. Lutz, M. Schniebel, E. Tuider. Springer, Wiesbaden, 2018, 663-672.

62 Midgley, C., Twells, A., Carlier, J. Introduction. - Women in Transnational History: Connecting the Local and the Global. Ed. by C. Midgley, A. Twells, J. Carlier. Routledge, London, 2016, I-IO, quotation: 4-5. See also Politische Netzwerkerinnen. Internationale Zusammenarbeit von Frauen, 1830-1960. Hrsg. von E. Schöck-Quinteros. (Schriftenreihe des Hedwig-Hintze-Instituts Bremen, Io.) Trafo-Verlag, Berlin, 2007; and, Women and Transnational Activism in Historical Perspective. Ed. by K. Jensen, E. Kuhlmann. Republic of Letters Publishing, Dordrecht, 2oro; Women's Activism and 'Second Wave' Feminism: Transnational Histories. Ed. by B. Molony, J. Nelson. Bloomsbury, London 2017.

63 Eliten im Vielvölkerreich. Imperiale Biographien in Russland und Österreich-Ungarn (I850-1918). Hrsg. von T. Buchen, M. Rolf. (Elitenwandel in der Moderne, 17). De Gruyter Oldenbourg, Berlin et al., 20I5; Imperial Subjects. Autobiographische Praxis in den Vielvölkerreichen der Romanovs, Habsburger und Osmanen im I9. und frühen 20. Jahrhundert. Hrsg. von M. Aust, F. B. Schenk. (Imperial Subjects. Autobiographik und Biographik im imperialen Kontext, I). Böhlau, Cologne, 20I5; and, Nach dem Zerfall der Imperien: Historische Zäsur und biografische Erfahrung im östlichen Europa. After the Fall of Empires: Historical Turning Points and Biographical Experience in Eastern Europe. Hrsg. von K. Steffen. (Nordost-Archiv. Zeitschrift für Regionalgeschichte 23 [2014]). Lüneburg 2015. 
Obviously, a transnational understanding does not need the nation state as an empirical unit. As a political entity where managing (ethnic/ religious) difference was the key challenge, empires in particular have been an object of re-evaluation recently, insofar as their endurance "challenges the notion that the nation-state is natural, necessary, and inevitable". ${ }^{64}$ In contrast to traditional fields such as international relations, or more contemporary directions like post-colonial history, the particular form of trans-border relations, be it of governmental or colonial character, is not important for the transnational perspective. Neither does this view need a definition concerning the status of actors, as in the case of political science where transnational relations need to be defined more strictly ${ }^{65}$ However, in trespassing the limited territoriality of the nation state, global contexts are not a precondition for transnational history either. ${ }^{66}$ In order to re-address the limitations caused by the fixation on state borders, scholars have recently argued for a more territorialised sense of transnationality in introducing the notion of "translocality" ${ }^{67}$ Thus, in contrast to global history, the frame of transnational history allows for limitations in space insofar as particular regions - which may or may not be contiguous and connected by particular networks - are put into focus. The territoriality of the nation state therefore provides only one spatial dimension among others ranging from the global to (supra- or subnational) regional to local and individual. ${ }^{68}$ "Playing with scales", it has been stated, is at the heart of transnational history as an innovative way to look into past phenomena. ${ }^{69}$

64 Burbank, J., Cooper, F. Empires in World History: Power and the Politics of Difference. Princeton University Press, Princeton, 20Io, 3; The Oxford World History of Empire. 2 vols. Ed. by P. Fibiger Bang, C. A. Bayly, W. Scheidel. Oxford University Press, Oxford, 2020; and, Osterhammel, J. Imperien. - Transnationale Geschichte, 56-67. On imperial Russia, see Weeks, T. R. Managing Empire: Tsarist Nationalities Policy. - Cambridge History of Russia. Vol. 2: Imperial Russia, 1689-1917. Ed. by D. Lieven. Cambridge University Press, Cambridge 2006, 27-44; and, Миллер, А. И. Империя Романовых и национализм. Әссе по методологии исторического исследования. Новое Литературное Обозрение, Москва, 2006; Imperium inter pares: Роль трансферов в истории Российской империи (І70о-1917). Отв. ред. М. Ауст, Р. Вульпиус, А. И. Миллер. Новое Литературное Обозрение, Москва, 2010.

65 See, for example, the definition by Pries, L. Die Transnationalisierung der sozialen Welt. Suhrkamp, Frankfurt 2007, I6: transnational relations may encompass state actors, but they necessarily include non-state actors.

66 The History of the European Union: Origins of a Trans- and Supranational Polity 1950-72. Ed. by W. Kaiser, M. Rasmussen, B. Leucht. Routledge, Abingdon, 2009; and Meyer, J.-H. Transnationale Geschichte.

67 Greiner, C., Sakdapolrak, P. Translocality: Concepts, Applications and Emerging Research Perspectives. - Geography Compass, 2013, 7, 5, 373-384. "Transregional" is named as another alternative to make it less normative. Conrad, S. What Is Global History?, 47-48.

68 Bayly, C. et al., On Transnational History, I446; and, Struck, B., Ferris, K., Level, J. Introduction, 576 . At least in the German context, the category of space was powerfully revived, with a particular focus on Eastern Europe, by Schlögel, K. Im Raume lesen wir die Zeit. Uber Zivilisationsgeschichte und Geopolitik. Hanser, Munich, 2003.

69 Struck, B., Ferris, K., Level, J. Introduction, 574, 576; and, Whelehan, N. Playing with Scales, 9 . 
Making sense of the interaction of this multitude of spatial dimensions is clearly one of the problems (and potentials) of the transnational perspective. To quote Rüger once more, one of the challenges of transnational history is to find "more imaginative ways of connecting micro and macro levels" ${ }^{70}$ According to Saunier, conflating location with country is one of the consequences of methodological nationalism that can be re-addressed with an understanding of space that goes beyond the traditional monopoly of national borders in organising spatial relations between actors. ${ }^{71}$ Individual experiences, large institutions or particular products such as cotton and sugar can serve as a common thread for a "global biography", ${ }^{72}$ providing an analysis in a spatial frame ranging from the local micro-scale to national (or global) macro-levels. Such a focus does not only offer the opportunity to analyse actors and (individual or cooperative) agency often missing from macro-level studies on cultures and societies. It also allows historians to make use of primary sources, which is often lacking in larger syntheses of global history. ${ }^{73}$ Still, the key obstacle for any kind of global or transnational scopes for research remains: hardly any individual is able to master all the necessary languages in order to maintain a certain balance between the different cultures (and scales) involved. Global narratives therefore predominantly depend on secondary literature.

It is true that the term transnational implicitly seems to postulate the existence of modern nations. ${ }^{74}$ Scholars, however, agree that its analytical scope is not limited to modern and contemporary processes, even if there is no consensus about the term making much sense for pre-modern or earlier contexts that predated the phenomenon of the modern nation. ${ }^{75}$ As a broader notion, however, transcultural history

70 Rüger, J. OXO, 66o. See De Vries, J. Playing with Scales: The Global and the Micro, the Macro and the Nano. - Past \& Present, 2019, 242, Issue Supplement I4: Global History and Microhistory, 23-36; and, the pledge for a "micro-spatial" approach to combine the virtues of the global and the micro levels in De Vito, C. G. History Without Scale: The MicroSpatial Perspective. - ibid., 348-372.

7I Saunier, P.-Y. Transnational History, 68-69.

72 "But in principle, any subject will do for a global biography." Conrad, S. What Is Global History, 7 .

73 Struck, B., Ferris, K., Level, J. Introduction, 577; for the examples of sugar and cotton see Mintz, S. W. Sweetness and Power: The Place of Sugar in Modern History. Viking, New York, 1985; Riello, G. Cotton: The Fabric that Made the Modern World. Cambridge University Press, Cambridge, 20I3; and, Beckert, S. Empire of Cotton. A Global History, Knopf, New York, 20I4.

74 Hirschi, C. The Origins of Nationalism: An Alternative History from Ancient Rome to Early Modern Germany. Cambridge University Press, Cambridge, 2012.

75 Yun-Casalilla, B. 'Localism', Global History and Transnational History: A Reflection from the Historian of Early Modern Europe. - Historisk Tidskrift (S), 2007, 127, 4, 659-678; Yun-Casalilla, B. Transnational History: What Lies behind the Label? Some Reflections from the Early Modernist's Point of View. - Culture \& History Digital Journal, 20I4, 3, 2, see the URL: http://dx.doi.org/I0.3989/chdj.2014.025 (last accessed 7 December 2020); and, Duindam, J. Early Modern Europe: Beyond the Strictures of Modernization and National Historiography. - European History Quarterly, 20I0, 40, 4, 606-623. 
can also be found to relate to medieval and early modern times with an extension of the cross-border focus to geographic, ethnic, religious and cultural boundaries. ${ }^{76}$ Especially for urban spaces, multi- or transculturality is indeed a rather common European heritage. According to Jeroen Duindam, specialists in early modern history thus "usually acknowledge 'transnational' patterns in the early modern age as a general and therefore arguably unremarkable phenomenon". ${ }^{77}$ In the same vein, Ulrike Strasser has stressed that, for example, early modern Germany was firmly "embedded in transnational historical processes at the time of the Reformation". ${ }^{78}$ Moreover, Catherine Holmes and Naomi Standen have made a claim for the "Global Middle Ages" because "the plentiful evidence for behaviour and interaction on a global scale in the millennium before I500 deserves sustained and precise analysis". ${ }^{79}$ In general, Armitage has summarised quite boldly that "there is now sufficient evidence from a sufficiently wide range of historiographies that these transnational connections have been determinative, influential and shaping throughout recorded human history" ${ }^{80}$ In the face of growing nationalist tendencies in European politics it may be the right time to indicate just these common traits during the pre-national ages. Transnational history is surely one of the ways to understand that "the creation of the 'European' in any space or part of the world through interaction" is perhaps the most important element in European history. ${ }^{81}$

Another case enlightening the political actuality of a transnational view is the broad field of migration studies for which, naturally, prenation conditions do not fundamentally change the basic juxtaposition of old and new cultural environments. The particular relationship in the

76 Borgolte, M. Migrationen als transkulturelle Verflechtungen im mittelalterlichen Europa. Ein neuer Pflug für alte Forschungsfelder. - Historische Zeitschrift, 2009, 289, 2, 26I-285; Kaiser, W. Transnationale Weltgeschichte im Zeichen der Globalisierung. - Geschichte der internationalen Beziehungen. Erneuerung und Erweiterung einer historischen Disziplin. Hrsg. von E. Conze, U. Lappenküper, G. Müller. Böhlau, Cologne, 2004, 65-92; here 66; cf. Meyer, J.-H., Transnationale Geschichte; Iriye, A. The Making of a Transnational World. - Global Interdependence, 682; and, Gassert, P. Transnationale Geschichte, Version: 2.o. - Docupedia-Zeitgeschichte, 29.IO.2012 (URL: http://docupedia.de/zg/ Transnationale_Geschichte_Version_2.o_Philipp_Gassert, 4.II.2O20), 3.

77 Duindam, J. Early Modern Europe, 6I5.

78 Forum: Globalizing Early Modern German History. - German History, 2013, 31, 3, 366-382, quotation 367 .

79 Holmes, C., Standen, N. Introduction: Towards a Global Middle Ages. - Past \& Present, 20I8, 238, Issue supplement I3: The Global Middle Ages, I-44, quotation I.

8o Ittersum, M. v., Jacobs, J. Are We All Global Historians Now?, I6.

8I Patel, K. K. Transnationale Geschichte. - Europäische Geschichte Online (EGO). Hrsg. vom Institut für Europäische Geschichte (IEG), Mainz (I2.03.20IO). URL: http://www. ieg-ego.eu/patelk-20Io-de (23.I0.2020); and, Oschema, K. Der Europa-Begriff im Hochund Spätmittelalter. Zwischen geographischem Weltbild und kultureller Konnotation. - Jahrbuch für europäische Geschichte, 200I, 2, 19I-235; Contesting Europe. Comparative Perspectives on Early Modern Discourses on Europe (I400-I80o). Ed. by N. Detering, C. Marsico, I. Walter-Bürgler. Brill, Leiden, 2020. 
migrants' minds between the destination and the home country provides the focus for an integrated transnational analysis. Recent scholarship thus deploys the term transnational migration as a phenomenon taking place within fluid social spaces that are "constantly reworked through migrants' simultaneous embeddedness in more than one society". ${ }^{82}$ Additionally, migration studies challenge the argument that transnational history deals only with elites because it refers to any interaction across borders between social hierarchies and different layers of society. ${ }^{83}$ Sociologist Riva Kastoryano even speaks of "transnational nationalism" in referring to trans-border communities as a global phenomenon today due to the massive presence of migrants. ${ }^{84}$

Strikingly, however, despite its global scope, Transnational History was received very unevenly in various academic cultures. Whereas there is a lively discussion of the issue in the USA, France and Germany, scholarly communities in countries such as Japan, Italy and Bulgaria, to name but a few, have been barely touched by it. ${ }^{85}$ Following Armitage, one might argue that for historians finding themselves in a post-colonial situation establishing a national narrative is essentially needed, in contrast to those colleagues who write from a post-imperial perspective, for whom - as in the former empires - a transnational approach is embraced. ${ }^{86}$ It would be too much for this introduction to go deeper into an analysis of local conditions (that still matter), but apart from general attachments of "national" histories with colonialism or other globalisation processes

82 Levitt, P., Jaworsky, B. N. Transnational Migration Studies: Past Developments and Future Trends. - Annual Review of Sociology, 2007, 33, I29-56, here I31; Glick Schiller, N., Basch, L. Theorizing Transnational Migration. - Anthropological Quarterly, 1995, 68, I, 48-63; Fouron, G., Glick Schiller, N. All in the Family: Gender, Transnational Migration, and the Nation-State. - Identities. Global Studies in Culture and Power, 200I, 7, 4, 539-582; and, Lionnet, F., Shumei, S. Introduction. - Minor Transnationalism. Ed. by F. Lionnet, S. Shumei. Duke University Press, Durham, 2005, I-26; A Century of Transnationalism: Immigrants and Their Homeland Connections. Ed. by N. L. Green, R. Waldinger. University of Illinois Press, Urbana, 2016. See a recent University of Tartu dissertation in Media and Communication Studies: Leppik, M. The Segmented Integration and Mediated Transnationalism of Estonian Russian-Speaking Populations. (Dissertationes de mediis et communicationibus Universitatis Tartuensis, 40.) University of Tartu Press, Tartu, 2020.

83 Meyer, J.-H., Transnationale Geschichte; Bayly, C. A. et al. On Transnational History, I460, I462; Borgolte, M. Migrationen als transkulturelle Verflechtungen; Jürgenson, A. Assimilatsionistidest transnatsionalistideni - rände ja integratsiooni uurimine 20. ja 2I. sajandil. - Tuna, 2016, 2, 9I-I05; Harders, L. Migration und Biographie. Mobile Leben beschreiben. - Österreichische Zeitschrift für Geschichtswissenschaften, 20I8, 29, 3, 17-36; and, Ghobrial, J.-P. A. Moving Stories and What They Tell Us: Early Modern Mobility Between Microhistory and Global History. - Past \& Present, 2019, 242, Issue Supplement I4: Global History and Microhistory, 243-228.

84 Kastoryano, R. Transnational Nationalism: Redefining Nation and Territory. - Identities, Affiliations and Allegiances. Ed. by S. Benhabib, I. Shapiro, D. Petranović. Cambridge University Press, Cambridge, 2007, 159-178.

85 Patel, K. K. Transnationale Geschichte; Ther, P., Comparisons; and, Clavin, P. Time, Manner, Place: Writing Modern European History in Global, Transnational and International Contexts. - European History Quarterly, 2010, 40, 4, 624-640.

86 Ittersum, M. v., Jacobs, J. Are We All Global Historians Now?, I7. 
there seems to be a clear connection with the readiness of national academic institutions to sustain alternative approaches especially in terms of integration in curricula (and thus popularising a new approach among a younger generation of scholars). There needs to be a generally shared sense of the necessity to look "beyond the nation" and a critical mass of practitioners if such a new paradigm for telling "our" story is to be established. Again, as Patel has maintained, transnational history "cannot completely deny its origin in emancipatory, leftist cultural milieus" with their urge for "a cosmopolitan alternative" substituting the nationalist agenda of state-legitimating historiography. ${ }^{87} \mathrm{Here}$, of course, we have one of the reasons why in post-Soviet spaces in particular a "transnational" approach might indeed be understood as something threatening to de-nationalise their own scholarly agenda.

\section{PLAYING THE TRANSNATIONAL GAME WITH THE ESTONIAN PAST}

Eastern Europe in particular is an interesting case. Already in 1994, Katherine Verdery pointed out that the term transnational carries a characteristic ambivalence. ${ }^{88}$ On the one hand, it can refer to what transnational means in the (anglophone) West - "spilling across sovereign polities" with no ethnic connotations. On the other hand, however, it can refer to something "spilling across ethnic communities", whether there is a (nation-) state or not, a process she calls "trans-ethnonational" for the sake of clarity. Verdery's distinction reminds us of the peculiarities of a region where ethnically mixed populations were rather the rule than an exception, where state borders have changed quite often in recent centuries and nation-states in particular became a reality relatively late in history, and were never stable. Whereas therefore national historiographies today are tempted to see the nation state as a focal point in the development of their respective national groups (and as a primary object of historiography), the quest for the transnational/transcultural

87 Patel, K. K. An Emperor without Clothes?

88 Verdery, K. Beyond the Nation in Eastern Europe, 4. Cf. on Eastern Europe specifically the approaches in Comparativ, 2008, 18, 2: Ostmitteleuropa transnational. Hrsg. von P. Haslinger; and Hadler, F., Middell, M. Transnationalisierung in Ostmitteleuropa bis zum Ersten Weltkrieg. - Handbuch einer transnationalen Geschichte Ostmitteleuropas. Bd. I: Von der Mitte des 19. Jahrhunderts bis zum Ersten Weltkrieg. Hrsg. von F. Hadler, M. Middell. Vandenhoeck \& Ruprecht, Göttingen, 20I7. Interestingly enough, the terminological difference explained by Verdery is not even mentioned here. See also New Perspectives in Transnational History of Communism in East Central Europe. (Dia-Logos, 26.) Ed. by K. Brzechczyn. Lang, Berlin, 2019. 
challenges this kind of teleology, or for that matter scientific-political agenda.

The ambivalence outlined by Verdery might be one additional reason why the term transnational has been introduced into Estonian humanities largely by art and literary scholars, but barely used so far by historians whose agenda is by and large still firmly rooted in the concept of a national past, marked by the boundaries of ethnically rooted national identities. ${ }^{89} \mathrm{~A}$ transnational, or for that matter transcultural setting, as has been laid out in the previous section, addresses precisely the entanglement of confessional, social, professional, rural and urban identities. ${ }^{90}$ In the Estonian case, many of these elements of an individual's identity have been fundamentally marked by ethno-cultural differences since the thirteenth century, which in the era of nationalism became encoded as markers of national antagonisms. No doubt, multi-ethnic empires - to which Estonian lands have belonged in the past to a substantial degree - are characterised, especially on their peripheries, by contact zones where transnational contacts and transfers between cultures create manifold entanglements. These contact zones are social environments where representatives of different cultures meet and clash, often in the context of asymmetrical power relations, which may or not have ethnic connotations, and often with individuals who decline nationalism's moral plea to commit oneself to just one singular (ethnic) community. ${ }^{91}$

89 Some examples of the use of the term in historical research (in the widest sense) include Plath, U. Kadunud kuldne kese. Kuus pilti Eesti ajaloost rahvusüleses kollaažis. - Vikerkaar, 2009, 7-8, 9I-98; Brüggemann, K. Mis teeb Eesti ajaloo ülejäänud maailmale huvitavaks? - Sirp, I7 October 20I0; Karjahärm, T. Eesti ajalugu: kas huvitav ainult näidisjuhtumina? - Sirp, Is October 2oro; Laanes, E. Wie es gewesen sein mag. - Keel ja Kirjandus, 20I2, 9, I23-I28; Jürgenson, A. Assimilatsionistidest transnatsionalistideni; Kaljundi, L. Mis on rahvusülene ajalugu? Intervjuu Karsten Brüggemanni ja Ulrike Plathiga, Saksa päritolu ajaloolastega, kes töötavad juba pikemat aega Eestis. - Sirp, 19.8.2016; Kaljundi, L., Plath, U. Eesti ajalookirjutus póimitud perspektiivist. - Tuna, 20I7, I, 2-6; Laanes, E. Trauma keelde tôlgitud: kultuurideülesed mäluvormid eesti küüditamis- ja laagrimälestustes. - Keel ja Kirjandus, 20I7, 4, 24I-257; Kaljundi, L., Kreem, T.-M. Ajalugu pildis - pilt ajaloos. Rahvuslik ja rahvusülene minevik eesti kunstis = History in Images - Image in History. National and Transnational Past in Estonian Art. Eesti Kunstimuuseum, Tallinn, 20I8; and, Special Issue: Entangled Cultures in the Baltic Region. Ed. by E. Laanes. - Journal of Baltic Studies, 2020, 5I, 3. See also the early debate between the literary scholar Jaan Undusk and the author of this article where Undusk's term "maiskondlik ajalugu", a kind of supra-national perspective for writing Estonian history, was criticised first and foremost in terms of unintended consequences: Undusk, J. Ajalootôde ja metahistoorilised žestid. Eesti ajaloo mitmest moraalist. - Tuna, 2000, 2, II4-I30; Brüggemann, K. Rahvusliku vaenlasekuju demontaažist ehk Carl Schirren kui Eesti iseseisvuse rajaja? Märkusi Jaan Unduski "metahistooriliste žestide" kohta. - Tuna, 2002, 3, 93-98; and, Undusk, J. Eesti ajaloo kotkaperspektiivist. Minu vaidlus Brüggemanniga. - Tuna, 2002, 3, 99-II6.

90 For an inspiring proposal on Ukraine, see Kappeler, A. From an Ethnonational to a Multiethnic to a Transnational Ukrainian History, 67.

9I Pietrow-Ennker, B. Einleitung: Konzept, Themen und Forschungsstrategien. - Russlands imperiale Macht. Integrationsstrategien und ihre Reichweite in transnationaler Perspektive. Hrsg. von B. Pietrow-Ennker. Böhlau, Cologne et al., 20I2, 9-34, quotation: 9-IO; Rosenberg, E. S. Transnational Currents in a Shrinking World. - A World Connecting, 813-996, quotation: 819-820; and, Pratt, M. L. Imperial Eyes: Travel Writing and Transculturation. $2^{\text {nd }}$ ed. Routledge, New York, 2008. 
Modern transcultural studies in the medieval and early modern history of Livonia and the Swedish Baltic provinces have already for some time addressed these questions. ${ }^{92}$ The even larger transnational environments of the Russian and Soviet empires, however, need much more attention in this respect.

To use the term trans(-ethno)national to relate to cross-cultural exchange within the boundaries of political entities, such as empires or pluricultural regions in general, might seem problematic only when taking an orthodox position concerning the semantic differences outlined by Verdery. If studying multiculturality in ethnically mixed regions is in danger of essentialising differences and often stresses inter-cultural conflict (not the least because that is what contemporaries mostly wrote about and later duly remembered), a transnational approach is able to look at the spaces in-between and the various forms of everyday contact, if sources allow. ${ }^{93}$

In the broader, non-anglophone European understanding of the term, transnational history can easily be applied to transgressions of imagined ethnic, religious, regional and cultural borders inside nationally constructed communities. ${ }^{94}$ Yet for the anglophone understanding of the "transnational" as "spilling over political entities" it was obviously necessary to address this issue in an authoritative intervention brought forward by two historians of the older generation under the aptly chosen title "Transnationalism in One Country?" and an accompanying analysis of cross-border migrations within the boundaries of the Soviet Union. ${ }^{95}$ In referring almost exclusively to English-language literature on migration issues and some examples of historical research using the

92 Livland - eine Region am Ende der Welt? Forschungen zum Verhältnis zwischen Zentrum und Peripherie im späten Mittelalter = Livonia - a Region at the End of the World? Studies on the Relations between Centre and Periphery in the Later Middle Ages. Hrsg. von A. Selart, M. Thumser. (Quellen und Studien zur baltischen Geschichte, 27.) Böhlau, Cologne, 2017; Making Livonia: Actors and Networks in the Medieval and Early Modern Baltic Sea Region. Ed. by A. Mänd, M. Tamm. Routledge, London, 2020.

93 To various degrees, the dangers and potentials of studying the local in the multicultural cities of the Baltic provinces of the Russian Empire are shown in Woodworth, B. D. Civil Society and Nationality in the Multiethnic Russian Empire: Tallinn/Reval I860-19I4. PhD diss., Indiana University, 2003; Hirschhausen, U. v. Die Grenzen der Gemeinsamkeit: Deutsche, Letten, Russen und Juden in Riga I860-19I4. Vandenhoeck \& Ruprecht, Göttingen, 2006. See also my attempt at a transnational approach, Брюггеманн, K. Города имперских и национальных утопий: транснациональный взгляд на Ригу и Таллин, 1914-1924. - Города империи в годы Великой войны и революции. Отв. ред. А. Миллер, Д. Черный. Нестор, Санкт-Петербург. 2ог7, Іоо-Із39.

94 See, among others, Gassert, P. Transnationale Geschichte, 3. For transnational research within the boundaries of the Hapsburg Empire, see Handbuch einer transnationalen Geschichte Ostmitteleuropas.

95 Siegelbaum, L. H., Moch, L. P. Transnationalism in One Country? Seeing and Not Seeing Cross-Border Migration within the Soviet Union. - Slavic Review, 2016, 75, 4, 970-986; and, Siegelbaum, L. H., Moch, L. P. Broad is my Native Land: Repertoires and Regimes of Migration in Russia's Twentieth Century. Cornell University Press, Ithaca, 2014. 
"transnational" umbrella referring to Soviet relations with "a series of externalities", Lewis H. Siegelbaum and Leslie Page Moch maintain that the term actually presupposes the crossing of international borders "because the nation and the state are assumed to be one and the same thing - a nation-state”. Completely ignoring the previous European debates on the term, they felt it necessary to add that the Soviet Union was never a nation-state. In fact, nobody needs to be reminded ${ }^{96}$ that the USSR was an entity containing many nations and "crossing borders defined as national did not mean leaving the country", a definition that is naturally also applicable to other multinational states. ${ }^{97}$ At the same time, coming from the broader Central European understanding of the term, Moritz Florin and Manfred Zeller go so far as to determine ethnically mixed Soviet urban milieus as "explicitly transnational" (which they undoubtedly were), even if Soviet cities actually functioned on the territory of ethnically fixed territories. Within these cities, they claim, "national folklore has to compete with the more cosmopolitan theater and the opera house, the national language [i.e. Russian] with the local lingua franca, and national history with the history of the city itself" ${ }^{98}$ Even if it might still sound a bit awkward for scholars from the anglophone world, transnational history can also prove its potential within the boundaries of any multinational state. Thus, in the Estonian case, a transnational agenda offers a reinvestigation of centre-periphery relations during the Soviet period, although one could also extend this approach back into the tsarist period. ${ }^{99}$

96 That the USSR was a "state of nations" has been widely accepted since the publication of the volume A State of Nations: Empire and Nation-Making in the Age of Lenin and Stalin. Ed. by R. G. Suny, T. Martin. Oxford University Press, Oxford 200 .

97 Siegelbaum, L. H., Moch, L. P. Transnationalism in One Country?, 973. Indeed, in $201 \mathrm{I}$ Michael David-Fox quite enthusiastically characterised the potential of transnational history for research on the USSR: "The first is the centrality of not just goods and people crossing actual borders but the way 'really-existing' exchanges were caught up with ideas and ideologies about the outside world, which deeply affected successive openings and closings; the second is the way those contacts, especially across the semipermeable membrane erected with the outside world in the Soviet period, illuminate the nexus between the Soviet system's external and internal dimensions." Interestingly, he did not mention crossing the internal borders of the Soviet national republics once. David-Fox, M. The Implications of Transnationalism, 904; see also David-Fox, M. The Iron Curtain as Semi-Permeable Membrane: The Origins and Demise of the Stalinist Superiority Complex. - Cold War Crossings: International Travel and Exchange across the Soviet Bloc, 1940s-1960s. Ed. by P. Babiracki, K. Zimmer. Texas A\&M University Press, College Station, 2014, I4-39.

98 Florin, M., Zeller, M. Soviet Transnationalism: Urban Milieus, Deterritorialization, and People's Friendship in the Late Soviet Union. - Ab Imperio, 20I8, 4, I3I-I46, quotation I34-I35.

99 Brüggemann, K., Woodworth, B. Entangled Pasts - Russia and the Baltic Region. - Russland an der Ostsee. Imperiale Strategien der Macht und kulturelle Wahrnehmungsmuster (16. bis 20. Jahrhundert) $=$ Russia on the Baltic: Imperial Strategies of Power and Cultural Patterns of Perception ( $16^{\text {th }}-2 \mathrm{O}^{\text {th }}$ Centuries). Ed. by K. Brüggemann, B. Woodworth. (Quellen und Studien zur baltischen Geschichte, 22.) Böhlau, Cologne et al., 2012, 3-26. 
If "playing with scales" is one of the rules to the game of Transnational History then it can be played with Estonian history as well. A fine-tuned study of trading Russian furs or wax via Reval to the ports of Western Europe could deal with the macro-level of Northern European trade relations, or the trans-Hanseatic networks of a Reval merchant; simultaneously connecting it with the micro-cosmos of Novgorodian hunters and beekeepers, the Reval "Marketplace" (immortalised by Lennart Meri), the crew of a Kogge on the Baltic Sea, as well as consumer culture in the receiving lands. ${ }^{100}$ Another example might be the life stories of imperial administrators, be it in the Swedish or Russian empires. Imagine the transnational biography of a Russian imperial (or for that matter Soviet) official who was born east of Moscow and later served the interests of the tsar in various provinces on the central Asiatic, Ukrainian and Baltic peripheries, encountering not only various ethnographic traditions and languages, but also different religious environments. How did these "imperial men", Baltic Germans among them, with all their transcultural experience shape the representation and concrete policies of the centre? How were they prepared to function as representatives of "their" non-Russian, non-Orthodox provinces in the centre? Our understanding of how the Russian Empire or the USSR were governed could be greatly enhanced if we address the different scales of the officials' activities, be it in the "all-imperial" or the particularly transnational "borderland context” ${ }^{101}$ At the same time, studying the careers of Estonian officials in the Russian imperial administrative network, ${ }^{102}$ or other Estonian professionals (military staff, managers of estates, nannies, etc.) making a career in the Empire might revise the common understanding of the

Ioo As an example, see Huang, A. Die Textilien des Hanseraums. Produktion und Distribution einer spätmittelalterlichen Fernhandelsware. (Quellen und Studien zur hansischen Geschichte, 7I.) Böhlau, Cologne, 20I5.

Ior On this differentiation, see Dolbilov, M. Russification and the Bureaucratic Mind in the Russian Empire's Northwestern Region in the r86os. - Kritika: Explorations in Russian and Eurasian History, 2004, 5, 2, 245-27I; and, as it was applied to the Baltic provinces, Brüggemann, K. Licht und Luft des Imperiums. Legitimations- und Repräsentationsstrategien russischer Herrschaft in den Ostseeprovinzen im 19. und frühen 20. Jahrhundert. (Veröffentlichungen des Nordost-Instituts, 2I.) Harrassowitz, Wiesbaden, 2018.

IO2 On the "Estonification" of officials in the Baltic provinces, see Woodworth, B. D. Patterns of Civil Society in a Modernizing Multiethnic City: A German Town in the Russian Empire Becomes Estonian. - Ab Imperio, 2006, 7, 2, 135-162; Woodworth, B. D. Paljurahvuselisus ja eestlastest riigiametnikud Eestimaa kubermangus aastatel I870-1914. Vene aeg Eestis. Uurimusi I6. sajandi keskpaigast kuni 20. sajandi alguseni. Koost T. Tannberg. (Eesti Ajalooarhiivi toimetised I4 [2I].) Eesti Ajalooarhiiv, Tartu, 2006, 34536o; Миллер, А. И. Империя Романовых, 63-64; Karjahärm, T. Aleksei Miller ja "uus impeeriumi ajalugu". - Tuna, 20II, 3, I36-I4I; Karjahärm, T. Vene impeerium ja rahvuslus. Moderniseerimise strateegiad. Argo, Tallinn, 20I2, I53-162; and, Brüggemann, K. Der imperial turn in Estland: Anmerkungen zu Toomas Karjahärms "Das Russische Imperium und der Nationalismus”. - Forschungen zur baltischen Geschichte, 2013, 8, 228-235. 
"Russification" context that has so far been seen as largely damaging to Estonian national emancipation, and moreover enhance our appreciation of the imperial scale of the Estonian past. Seen in this context, even gaining independence in 1918 might have been a much more "imperial" process than has been hitherto acknowledged. ${ }^{103}$

To think of nineteenth and early twentieth century topics that might be studied with a transnational approach is not difficult. They range from the top of the social hierarchy - the ties of the Baltic German aristocracy with their peers within and outside the Russian Empire - to its very bottom - the transnational networks of the emerging workers' movement. The latter might also provide new insights into the aftermath of the 1905 Revolution, when many Estonian activists were forced to flee their home provinces to other parts of the Empire, or elsewhere in Europe. A transnational environmental history of the "last great European famines", which also hit the Baltic provinces during the $1840 \mathrm{~S}^{104}$ is missing; as is a close study of the economic ties that bound the Baltic provinces' merchants to the rest of the Empire and the outer world. Concerning the latter, two on-going German projects may fill this gap in the future: Katja Wezel's investigation of the imperial ties of the merchants of Riga in the early twentieth century, and David Feest's biographical research on one of the most important Estonian bankers during the interwar period, Klaus Scheel (1890-196I), who certainly lived a transnational life between the continents. ${ }^{105}$

Our project does not dwell in the Soviet period of Estonian history, even if Baltic Communists are the topic of Magnus Ilmjärv's research on

I03 See Brüggemann, K. Yearning for Social Change: The Russian Revolution in the Baltic Provinces. - Studies in Ethnicity and Nationalism, 2017, 17, 3, 358-368; and, Brüggemann, K. Learning from Estonia Means Learning to Be Victorious? Estonia between the Legacy of the February Revolution and Nikolai Iudenich's Northwestern Army. - The Global Impacts of Russia's Great War and Revolution, Book r: The Arc of Revolution, 1917-24. Ed. by A. Marshall, J. W. Steinberg, S. Sabol. Slavica, Bloomington, 2019, 99-I29.

IO4 Newby, A. N., Myllyntaus, T. 'The Terrible Visitation': Famine in Finland and Ireland, I945 to 1868. Towards an Agenda for Comparative Irish-Finnish Famine Studies. - Famines in European Economic History. The Last Great European Famines Reconsidered. Ed. by D. Curran. (Routledge Explorations in Economic History, 7I.) Routledge, London et al., 2015, I45-165; and, Lust, K. The Question of Moral Economy and Famine Relief in the Russian Baltic Provinces of Estland and Livland, I84I-69. - Collegium: Studies across Disciplines in the Humanities and Social Sciences, 2017, 22, 46-66.

Ios Wezel, K. Transcending Boundaries: Riga's Baltic German Entrepreneurs in an Era of Nationalism, Revolution, and War. - Journal of Baltic Studies, 20I7, 48, r: Baltic German Perceptions of Belonging in the Nineteenth and Twentieth Century, 39-54; Feest, D. Spaces of 'National Indifference' in Biographical Research on Citizens of the Baltic Republics I918-I940. - Journal of Baltic Studies, 2017, 48, I: Baltic German Perceptions of Belonging in the Nineteenth and Twentieth Century, 55-66; and, Feest, D. Klaus Scheel, Estlands ungekrönter König. Eine biografische Skizze. - Individuum und Gesellschaft in Ost- und Nordosteuropa. Hrsg. von J. Tauber. Nordost-Institut, Lüneburg, 2017. URL: www.ikgn. de/online-publikationen/forschungsbeitraege/individuum-und-gesellschaft (last accessed ${ }_{17}$ December 2020). 
transnational interwar networks in the framework of the Comintern. Far from being limited solely to migration patterns across the internal Soviet borders, a transnational view of that time could be applied to various forms of analysing the "brotherhood of nations" discourse that backed up the official doctrine of internationalism as the kit of the Soviet multinational state. How this axiomatic ideological pattern - that was officially framed with the commitment of the state to the blossoming of (socialist) national cultures - could even contribute to a (re)nationalisation of, for example, particular artists, has been demonstrated by the art historian Kädi Talvoja. ${ }^{106}$ Besides the dominant cultural connections between the Russian "centre" and the non-Russian peripheries, there was a network of mainly bilateral relations between the republics which sometimes even circumvented the centre, ranging from weeks of culture of a brotherrepublic to joint curricula of universities in different SSRs. ${ }^{107} \mathrm{~A}$ thorough analysis of the policy of the central "thick" journal Druzbba narodov might be a thrilling topic for research, especially using the perspective of peripheral literatures. The trans-union success of Estonian pop-stars like Jaak Joala and Anne Veski is also waiting for its researchers, ${ }^{108}$ whereas the effect of Estonian Jazz on a Union-wide scale has already been analysed by Michel Abeßer. ${ }^{109}$

What this collection of articles aims to demonstrate is the embeddedness of Estonian lands in transnational historical processes since medieval times. From the thirteenth century onwards, competing visions of what it meant to be Catholic/Protestant, German, undeutsch, Estonian, etc., had to be articulated in reference to a world that reached beyond the borders of parishes, towns, provinces or states. As a result, these visions eventually influenced local social structures, cultural traditions and

Io6 Talvoja, K. (Re)nationalizing Estonian Art During the Thaw: Lively Legacy of Kristjan Raud. - A Socialist Realist History? Writing Art History in the Post-War Decades. Ed. by K. Kodres, K. Jõekalda. (Das östliche Europa. Kunst- und Kulturgeschichte, 9.) Böhlau, Cologne, 2018, 170-199.

IO7 Studies on transnational literary relations in the case of the Lithuanian SSR have been already published. See Ivanauskas, V. İrėminta tapatybė. Lietuvos rašytojai tautų draugystès imperijoje. Lietuvos istorijos instituto leidykla, Vilnius, 20I5. In general, see Dobrenko, E. Soviet Multinational Literature: Approaches, Problems, and Perspectives of Study. - The Literary Field under Communist Rule. Ed. by A. Jurgutiené, D. Satkauskyte. Academic Studies Press, Boston, 2018, 3-17. On joint curricula between the Tallinn and Kaunas Polytechnical Institutes, see Graf, M. Rahvuskommunistid. Enn-Arno Sillari ja teised. Argo, Tallinn, 2020, I4-I5.

Io8 With a focus on the Estonian audience: Reimann, H. Jaak Joala - 'Kremlin Nightingale' or Estonian Ccelebrity? - Celebrity Studies, 2020, II I, I49-I52.

Io9 Abeßer, M. Progressiv weil national? Estland und die Neuerfindung des sowjetischen Jazz zwischen 1953 und 1970. - Jahrbücher für Geschichte Osteuropas, 2019, 67, 3, 424-446. See Reimann, H. Eesti nôukogudeaegse kultuuri tähendusväljadest hilisstalinismiaegse džässiajaloo näitel. - Acta Historica Tallinnensia, 2016, 22, 89-III. 
the representation of local issues on a broader level, i.e. socio-spatial dynamics in translocal contexts, multidirectional and overlapping networks that facilitate the circulation of people, resources, practices and ideas. Non-national, non-state actors, such as religious communities, imperial officials, international organisations and migration networks have played a crucial role in this context. Individuals and groups of people, as a rule, become actors not as members of a national community, but as migrants, students, teachers, priests and network activists. ${ }^{110}$ Estonian society, as such, throughout history formed a multi-layered playground where borders in terms of social status, language, ethnic background and religion were constantly activated and challenged.

The articles collected here deal with transcultural networks that were active in, but by no means limited to, the German language area the initially Catholic and later Protestant space in Europe's north. This space effectively formed a trans-Baltic diffusion area of knowledge and cultural practices that continued to exist in various imperial spaces with different cultural environments. One of the ways in which this diffusion could manifest itself was the practices of Catholic faith, among them the veneration of saints. In her contribution, Inna Póltsam-Jürjo follows the traces of the Cult of St Anthony from Central Europe to medieval Livonia, and from the local urban German upper classes to rural Estonians. It has been noted that due to the local society's insufficient political and cultural integration, and the trans-regional identity of the elites, local saints lost importance and had to make space for universal Catholic saints. ${ }^{111}$ Despite the scarcity of sources, Pôltsam-Jürjo demonstrates how as a result of the transfer of the Saint to Livonia, local society adapted the tradition with the addition of their own layer of meaning. If for the German elites, both secular and clerical, St Anthony was primarily seen as helper against diseases and possibly also of those who faced purgatory, the Estonian common folk venerated him as the patron saint of pigs and other domestic animals, thus providing him with vital meaning in everyday life. In this transcultural process, a foreign idol was effectively "domesticised" and through his veneration peoples' imagination and creativity in shaping religious customs become explicit.

Another aspect that demonstrates the active role of the Northern European diffusion area in the Baltic provinces was the exchange of education practices. In his earlier research, Aivar Póldvee has already

IIo Iriye, A. The Making of a Transnational World, 682.

III Selart, A., Mänd, A. Livonia - a Region without Local Saints? - Symbolic Identity and the Cultural Memory of Saints. Ed. by N. H. Petersen, A. Mänd, S. Salvadó, T. R. Sands. Cambridge Scholars Publishing, Newcastle upon Tyne, 2018, 9I-I22. 
dealt with this kind of cultural transfer during the medieval and early modern periods. ${ }^{112}$ In his contribution to this issue, he continues following (among others) inter-imperial transfers from the British to the Russian Empire in the early nineteenth century in terms of education ideas. Thus, Otto Wilhelm Masing (1763-1832), one of the first Estonian intellectuals, became influential in spreading pedagogical innovations initiated by "clever men" in India and England, Andrew Bell (1753-1832) and Joseph Lancaster (1778-1838), to the Estonian reading public. Via the Russian Empire the ideas of Johann Heinrich Pestalozzi (1746-1827), whose name was known to Alexander I (1777-1825) thanks to the liberal minds at his court, among them Georges-Frédéric Parrot (1767-1852), the rector of the University of Tartu (Ger. Dorpat) that was re-opened in I802, reached the Baltic provinces. In I804, Parrot even invited Pestalozzi to Tartu to implement his ideas in a school reform, but Pestalozzi refused. In general, Pôldvee maintains that transnational flows reaching the Baltic provinces have so far been neglected in Estonian historical research. Moreover, they were by no means limited to the German cultural area, but could also come from the English- or French-speaking worlds.

Transnational migrations, so typical of educated European men of the era of the Enlightenment, were something the Baltic provinces definitively needed, as Priit Raudkivi demonstrates, at least before the mid-nineteenth century when the University of Tartu established itself as the leading institution in the littoral to produce intellectuals locally. Estonian historiography traditionally dealt with these German learned men, the so-called literati, who migrated to the Baltic provinces during the eighteenth and nineteenth centuries as if they were, to a large degree, local. To draw attention to the cultural baggage these men carried with them from Germany is a huge task given the difficult situation with sources. Usually, these men initially sought employment as home teachers with the Baltic German nobility in order to later attain a position as a parish pastor. One of the ways of assessing their impact is a thorough analysis of the church chronicles these men produced as pastors. Based on his interest in environmental history, Raudkivi argues that the effort some of these migrants put into recording information on local climate conditions is one of the more obvious elements of their intercultural

II2 Póldvee, A. Die langsame Reformation: Luthertum, Schrifttum und die estnischen Bauern im I6.-17. Jahrhundert. - Wandel und Anpassung in der Geschichte Estlands. 16.-20. Jahrhundert. Ed. by K. Brüggemann. (Nordost-Archiv: Zeitschrift für Regionalgeschichte, XXII/2013.) Nordost-Institut, Lüneburg, 2014, 56-88; Póldvee, A. 17th Century Estonian Orthography Reform, the Teaching of Reading and the History of Ideas. - Trames: Journal of the Humanities and Social Sciences, 20II, 15, 4, 365-384. 
impact, and an indication of the transnational intellectual currents that to some extent shaped the spiritual outlook of the Baltic lands during the age of Enlightenment and beyond.

Estonian emigration has always been at the top of Aivar Jürgenson's research agenda. He is a prolific expert in different waves of Estonian emigration, be it to Latin America, Siberia or the Caucasus region. ${ }^{113}$ However, his latest research on Estonian settlers in Abkhazia during the nineteenth and early twentieth centuries, a particular form of intra-imperial migration, focuses on Lutheran pastors who often travelled between their homeland and the settlement area. Even if there were not only ethnic Estonians among them, they served as brokers of Estonianness and secured the cultural commitment of these settlements - which lived isolated amongst their Orthodox and Muslim surroundings - to their homeland. It appears that, following Jürgenson's findings, it was relatively easy to maintain these connections under the umbrella of imperial common structures; it is a completely different problem to continue this exchange across the borders of national states. Together, Raudkivi and Jürgenson demonstrate the eminent role Protestant clergy played through the centuries, as carriers of the Enlightenment and Estonianness.

Nevertheless, since the early twentieth century, an almost global spatial connectedness has to be assumed that not only considerably widened the range of Estonian emigration (to places from Siberia to the Americas), but also created the potential of networking in transnational, globally active organisations such as the Comintern and the International Labour Organisation (ILO), the two examples that are discussed in this issue. Hitherto, the study of international organisations in general has focused on their utility and relations to other institutions, notably the nation state. ${ }^{14} \mathrm{~A}$ closer examination can draw out the degree to which internationalism, transnationalism and multinationalism coexisted in the framework of these bodies. ${ }^{115}$ Whereas the ILO was an international agency of the League of Nations explicitly founded to face the communist threat, the Comintern - as representation of the communist world revolution that had not materialised immediately

II3 See, among other works, his monographs: Jürgenson, A. Siberiga seotud. Eestlased teisel pool Uuraleid. Argo, Tallinn, 2006; and, Jürgenson, A. Ladina rahva seas. Argentina ja sealsed eestlased. Argo, Tallinn, 2011.

II4 For the Estonian case, see Made, V. Külalisena maailmapoliitikas. Eesti ja Rahvasteliit 1919-1946. Tartu Ülikooli Kirjastus, Tartu, I999.

II Clavin, P., Wessel, J. W. Transnationalism and the League of Nations: Understanding the Work of Its Economic and Financial Organisation. - Contemporary European History, 2005, I4, 4, 465-492, quotation 466-467. 
after 1917 - was an organisation with global ambitions, a "world party with national sections" without necessarily representing nation states. In terms of communication, activity and agency, and with it practices of being active beyond and in-between national entities, the Comintern was both an inter- and transnational organisation, which is also true of the biographies of its protagonists. ${ }^{116}$ So far, Estonian historiography has not dealt in detail with the transnational quality of Estonian socialism and the introduction of international standards in labour regulation during the interwar period. Magnus Ilmjärv examines the entanglement of communists from the Baltic states with the Comintern. Who actually were the people representing the littoral in this organisation? How did the multinational staff of the Comintern deal with national issues? How did structural changes in the organisation mirror the Soviet viewpoint concerning a future Baltic revolution?

Maie Pihlamägi in her pioneering article on the ILO in Geneva traces the effect its resolutions had on social politics in interwar Estonia. In her contribution, she offers an overview on social legislation in Europe before and after the Great War, and discusses the local conditions necessary in Estonia for successful implementation of the advice of the Geneva-based organisation. ${ }^{117}$ It is hardly surprising that in realising the resolutions, national interests were decisive as the ILO had no effective mechanisms at its disposal to force its members to apply its standards. Nevertheless, as Pihlamägi shows, Estonia's commitment to the ILO forced the young country to take part in the international competition in granting social standards to its citizens. As a result, the country's delegates to Geneva took part in public discussions on this issue where standards granted in other countries played a major part in the argumentation. Interestingly, the voting behaviour of the delegates in Geneva was rarely uniform since they represented the interests of the country's workers, employers and the state. A thrilling research agenda for the future would be to look closer at the activities of these men (no women

II6 Studer, B. Die Komintern. Herrschaftspraktiken, Machtmechanismen, kollektive und individuelle Handlungsspielräume. - Russlands imperiale Macht, 229-257, quotation: 229-230; Studer, B. The Transnational World of the Cominternians. Palgrave Macmillan, Houndmills, 2oI5; Studer, B. Reisende der Weltrevolution. Eine Globalgeschichte der Kommunistischen Internationale. Suhrkamp, Berlin, 2020.

II7 The latest research (without specific connection to the Baltic states) includes The Internationalisation of the Labour Question: Ideological Antagonism, Workers' Movements and the ILO since 1919. Ed. by S. Bellucci, H. Weiss. Palgrave Macmillan, Cham, 2020; Women's ILO: Transnational Networks, Global Labour Standards and Gender Equity, I919 to Present. Ed. by E. Boris, D. Hoehtker, S. Zimmermann. (Studies in Global Social History, 32.) Brill, Leiden/Boston, 20I8; and, Globalizing Social Rights: The International Labour Organization and Beyond. Ed. by S. Kott, J. Droux. Palgrave Macmillan, Houndmills, 20I3. 
were ever delegated from Estonia) behind the scenes of the meetings in Switzerland.

Both papers on the transnational activism of Estonians during the interwar period illustrate the need for a wider understanding of the nation's path during this period of accelerating cross-border communications. Particularly Ilmjärv's section on the Comintern demonstrates that not all interconnections and transnational flows necessarily served the common pursuit of happiness and the good of humanity. As Klaus Kiran Patel and Sven Reichardt remind us, there are also darker sides of transnationalism, such as the projects of social engineering inspired by Nazism (and for that matter Stalinism) with their considerable transnational impact that have not yet received the attention they deserve. ${ }^{118}$ Yet a modest collection of articles cannot possibly cover all the potential of such a broad approach as the transnational. As the editor, I would be happy if this special issue contributes to the fostering of the understanding that Estonian history does not stop at the border of the modern nation state. After all, as Estonians like to quote, Ernest Hemingway (1899-1961) was aware that one may find Estonians in every harbour in the world (even if in his novel To Have and Have Not he simply remarked that every "well-run yacht basin in Southern waters" would not be "complete without at least two sunburned, salt bleached-headed Esthonians”). ${ }^{119}$

Alas, not even the image of the experienced and globally active Estonian seafarer can survive the transnational turn unspoiled. As we know today, during the I920s Estonian sailors took part in the transnational liquor smuggling networks across the Baltic Sea that were much wider than hitherto assumed. ${ }^{120}$ As Adrian Mitter demonstrates, Estonian crews could easily serve on a Finnish trawler under an Austrian flag, and in times of danger, when they were, for instance, caught by the Finnish coast guard and abandoned by Austria in the course of a diplomatic conflict, switch their allegiance to a Greek company via

II8 See the introduction of the special issue Patel, K. K., Reichardt, S. Introduction: The Dark Side of Transnationalism: Social Engineering and Nazism, 1930s-40s. - Journal of Contemporary History, 20I6, 5I, I, 3-2I.

II9 Quoted in Tarand, A. The Soviet Period. - Estonia: Identity and Independence. Ed. by. J.-J. Subrenat (On the Boundary of Two Worlds, 2.) Rodopi, Amsterdam, 2004, I37-I52, here I42; Vesilind, P. Eestlane igas sadamas. Varrak, Tallinn, 2004, I2. On the conflicting and conflating identities of Estonians between the role model of the patriotic 'peasant' and the cosmopolitan 'sailor' see Brüggemann, K. The Eastern Sea is a Western Sea: Some Reflections on Estonia as a Baltic Sea Country. - The Baltic as a Multicultural World: Sea, Region and Peoples. (The Baltic Sea Region: Nordic Dimensions - European Perspectives, 4.) Ed. by M. Lehti. Berliner Wissenschafts-Verlag, Berlin, 2005, 59-79.

I2o Pullat, R., Pullat, R. Viinameri. Salapiiritusevedu Läänemerel kahe sõja vahel. Estopol, Tallinn, 2 oı. 
their connections in the tax-free area in the port of Danzig. Thus they could effectively circumvent the terms of the Helsinki Convention for the Suppression of the Contraband Traffic in Alcoholic Liquors of 1925, which neither Austria nor Greece had signed. "Without leaving Baltic waters, the smuggling ship miraculously sailed from Austrian ship registers to its new official Greek home port of Poros in the Aegean Sea", Mitter points out. ${ }^{121}$ Thus, Estonian liquor smugglers may have made a fortune in effectively using transnational connections in order to undermine international anti-smuggling activities in the Baltic Sea rim. No wonder then, that during the interwar period it was the Estonian Viking (who may or may not have destroyed Sigtuna) who became the embodiment of the nation's virtues, ${ }^{122}$ and not the liquor smuggler. The activities of both, however, went beyond the borders of Estonian lands and deserves to be addressed in a transnational frame. The history of the nation can only benefit from any exploration across the manifold boundaries constructed to enshrine "Estonia".

\section{Acknowledgements}

This article has been prepared in the framework of project IUT3I-6 funded by the Estonian Research Foundation: A Transnational Setting for Estonian History: Transcultural Entanglements, International Organisations and Transborder Migrations ( $\mathrm{I}^{\text {th }}-2 \mathrm{I}^{\text {st }}$ Centuries). The author wishes to thank James Baxenfield for proofreading the article and Airi Uuna for translating the summary into Estonian.

I2I Mitter, A. Rum Runners of the Baltic - The Rise of Transnational Liquor Smuggling Networks in Interwar Europe. - Zeitschrift für Ostmitteleuropa-Forschung, 2019, 68, 4, 527-550, quotation 544 .

I22 Kaljundi, L. Challenging Expansions. Estonian Viking Novels and the Politics of Memory in the 1930s. -Novels, Histories, and Novel Nations: Historical Fiction and Cultural Memory in Finland and Estonia. (Studia Fennica, 19.) Ed. by L. Kaljundi, E. Laanes, I. Pikkanen. Suomalaisen Kirjallisuuden Seura, Helsinki, 182-207. 


\section{RAHVUSÜLENE AJALUGU JA RAHVUSE AJALUGU: EESTI JUHTUM}

\section{Karsten Brüggemann}

Käesolev artikkel uurib, mida pakuvad rahvusülesed perspektiivid Eesti ajaloole uurimisele, ja näitab, miks selline lähenemine vôiks olla huvipakkuv laiemale publikule. Selleks tutvustatakse Acta Historica Tallinnensia teemanumbri siinses sissejuhatuses rahvusülese ajalookäsitluse pôhilisi môisteid ja lähenemisi, hinnatakse sellise käsitluse suuremaid väljakutseid ning vaetakse rahvusülesuse ja rahvuslikkuse tiheda vahekorra üle. Arutletakse ka küsimuse üle, miks on rahvusülene ajalookäsitlus just nüüd ja ainult teatud ajalookirjutuse traditsioonides, iseäranis mónes Euroopa piirkonnas ja Ameerika Ühendriikides, muutunud vôrdlemisi populaarseks. Eraldi alaosas visandatakse rahvusülese lähenemise üldjooned, vaadeldes peamiselt Eesti lähiajalugu, kus, erinevalt varasematest ajalooperioodist, pole rahvusülesed suunitlused teadlaskonnas nii kesksel kohal. Lópetuseks tutvustatakse ajakirja teemanumbri artikleid, mis on sündinud Eesti Teadusagentuuri aastatel 20I5-2020 toetatud projekti tulemusena.

Eesti ajaloo kirjutamisel pakub rahvusülene raamistik alternatiivi nii Kulturnation'i mõistel põhinevale historiograafilisele traditsioonile, mis on alates I99I. aastast väga iseloomulik Ida-Euroopa ajalookäsitluses, kui ka "suure vabadusvôitluse" (M. Tamm) narratiivsele mallile. Rahvusülene ajalookäsitlus on kui koondperspektiiv, mis tôukub teadlaskonna kasvavast huvist riigipiiriüleste protsesside vastu - ülekanded, seosed, ringlused jms. Kuna rahvusülest ajalugu nähakse kui pragmaatilist lähenemisvõimalust, kui vaatepunkti, millel puudub ühtne teooria või spetsiifilise uurimismeetod, siis valitseb üldine konsensus, et käsitluse üks eelistest on metodoloogiline avatus.

Rahvusülene raamistik keskendub kultuuridevahelistele põimumistele ja pöörab enam tähelepanu aspektidele, nagu piiride ja piirangute läbilaskevôime vôi territoriaalsuse ja ruumi korrastatus, kui traditsiooniline rahvusvaheline ajalookäsitlus vối sotsiaalajalugu. Kindlasti ei püüa rahvusülene ajalugu olla histoire totale ja hôlmata peaaegu kóike, sest mitte iga ajaloonähtuse puhul polegi vaja näha vôi otsida rahvusülest môoódet.

Rahvusülene lähenemine ei tähenda, et (Eesti) rahvuslust kui ajalooliselt liikumapanevat jõudu hakatakse dekonstrueerima. See pigem relativeerib rahvuse kui analüütilise raamistiku vaieldamatut esmasust ja suunab tähelepanu asjaolule, et rahvuslus on konstrueeritud johtudes 
rahvusvahelisest vajadusest. See tähendab, et rahvusülene ja rahvuslik pole üksteist välistavad, vaid pigem on tegu ühe nähtuse kahe variatsiooniga, mis keskenduvad paralleelsetele, ent üksteisega tihedalt seotud arengutele minevikus.

Tänapäeva ajalookirjutuses domineerib suuresti rahvuslik historitsism, hoolimata sellest, et rahvusliku ajalookäsitluse kirjutamiskeskkond on viimaste kümnendite jooksul oluliselt muutunud, mis on lubanud tuntud ideedeajaloolasel David Armitage'il kuulutada, et "rahvusliku historiograafia hegemoonia on möödas”.

Hiljutised "kuumad" piiriülesed teemad, nagu terrorism, inimõigused, sport, turism ning haiguste levik ja katastroofide tagajärjed, on saanud tähelepanu rahvusüleses vôtmes. Individuaalseid kogemusi, suuri institutsioone vôi teatud tooteid, nagu puuvilla vôi suhkrut, on analüüsitud rahvusüleselt. Biograafilistes uuringutes on huvi keskmesse tôusnud "rahvusvahelised toimijad", kelle elulookirjutajad ei vôta uurimisraamistikuks mitte rahvust, vaid mobiilsust. Just naiste rahvusülesed elud on sattunud teadustöö huvisfääri, vastandudes sellega traditsioonilisele käsitlusele, mis asetab mehed "globaalsele" ja naised "kohalikule" areenile, ning näidates sellega empiiriliste lokaaluuringute vôimekust senist tervikpilti küsimuse alla seada.

Rahvusülene ajalugu kuulub uurimissuundade hulka, mis keskenduvad ajaloolistele kokkupuutepunktidele, póimumistele ja seostele, relativeerides sel viisil rahvust kui analüüsiprismat. Artikkel visandab rahvusülese perspektiivi suhet teiste nüüdisaegsete mineviku käsitlemise vôimalustega, nagu "põimitud ajalugu” (entangled history) vôi " histoire croisée” ning "maailma ajalugu” või "globaalne ajalugu”. Need on kôik saanud osaks innustavast debatist, mõtestades universaalajalugu millegi rohkema kui pelgalt narratiivivormina, kus kórvutatakse rahvuslikke ajalugusid. Eriti paljulubavana näib rahvusülene käsitlus sellistel aladel, nagu migratsiooniuuringud vôi imperiaalajalugu. Pole kahtlustki, et selline perspektiiv minevikule vôib tõestada oma võimekust ka ükskõik millises mitmerahvuselises riigis, sealhulgas Vene impeeriumis ja Nóukogude Liidus.

Hoolimata oma globaalsest haardest, varieerub erinevates akadeemilistes kultuurides rahvusülese ajalookäsitluse vastuvôtt. Kui USAs, Prantsusmaal ja Saksamaal on selle teemaga kaasnenud elav arutelu, siis riikides, nagu Jaapan, Itaalia ja Bulgaaria, pole see teema teaduskogukondi peaaegu üldse kônetanud. Armitage’i eeskujul võib väita, et ajaloolastele, kes leiavad end koloniaalajastu järgses olukorras, on rahvusliku narratiivi loomine hädavajalik. Seevastu nende kolleegid, kes oma ajalookirjutuses 
lähtuvad post-imperiaalsest perspektiivist (näiteks endistes impeeriumides), on rahvusülese lähenemise juba omaks vôtnud.

"Rahvuslike" ajalugude sidemete kõrval, mis on seotud kolonialismi vôi muude globaliseerumisprotsessidega, näib sel olevat selge seos rahvuslike akadeemiliste institutsioonide valmidusega soodustada alternatiivseid lähenemisviise, integreerides neid óppekavadesse (ja seeläbi populariseerides uusi lähenemisviise nooremate teadlaste seas). Uue paradigma juurdumine "meie" loo jutustamiseks nôuab nii üldsuse poolt tunnustatud vajadust vaadata "rahvusest kaugemale" kui ka teatud hulka uurijaid. Eriti postsovetlikus ruumis vôib "rahvusülene” lähenemine, mis justkui muudaks kohaliku teadusagenda mitterahvuslikuks, mójuda ähvardavana.

Käesolev teemanumber püüab näidata, kuidas tänase Eestiga seotud maa-alad on juba keskajast saati kaasatud rahvusülestesse ajalooprotsessidesse. Alates I3. sajandist on omavahel vôistelnud visioonid sellest, mida tähendab olla katoliiklane või protestant, sakslane, undeutsch, eestlane jne. Neid aspekte môtestades tuli suhestuda maailmaga, mis oli suurem, kui oma kihelkonna-, linna-, provintsi- vối riigipiir. Need visioonid môjutasid kohalikke sotsiaalseid struktuure, kultuuritraditsioone ja paiklike teemade esitlemist laiemal tasandil, seega sotsiaalruumilisi dünaamikaid translokaalsetes kontekstides, mitmesuunalistes ja kattuvates vôrgustikes, mis hôlbustavad inimeste, ressursside, praktikate ja ideede liikumist. Selles kontekstis on mänginud olulist rolli mitte-rahvuslikud, mitte-riiklikud toimijad, nagu religioossed kogukonnad, impeeriumite ametnikud, rahvusvahelised organisatsioonid ja migratsioonivôrgustikud. Üksikisikud vôii inimgrupid ei muutu reeglina toimijateks rahvusliku kogukonna liikmetena, vaid migrantide, tudengite, ôpetajate, preestrite vôi vốrgustikuaktivistidena. Eesti ühiskonnas on ajaloo jooksul välja kujunenud mitmetasandiline mänguruum, kus piirid sotsiaalse staatuse, keelelises, etnilise tausta ja religiooni móistes on pidevas muutumises. 